Advances in Agroforestry 11

- Pablo Luis Peri

Francis Dube

Alexandre Varella Editors

Silvopastoral

Systems in

Southern South

America

Springer 


\title{
Silvopastoral Systems in the Cold Zone of Brazil
}

\author{
Alexandre Costa Varella, Raquel Santiago Barro, \\ Jamir Luis Silva da Silva, Vanderley Porfírio-da- \\ Silva, and João Carlos de Saibro
}

\begin{abstract}
The cold zone of Brazil occupies approximately $6 \%$ of the national territory and is located between latitudes $24^{\circ} \mathrm{S}$ and $33^{\circ} \mathrm{S}$. In this area, extensive cattle and sheep farming systems and conventional cropping and forestry are predominant. With the end of government subsidies by the decade of 1980s, an increase in farming production costs, a decrease of native forest covering, an increase of degraded areas in agriculture and livestock farming systems and a mismatch between timber national supply and demand after 1990s, an opportunity arises for integrate forestry with livestock and agriculture activities in Brazil, particularly in the southern. This chapter initially reports key events over the last three decades that have supported the increasing interest of farmers and enterprises on agroforestry activities, with focus on silvopastoral systems in the cold area of Brazil. Then, relevant advances on silvopastoral systems from research and extension services were reported, highlighting the screening of shaded adapted forage plants and management, trees species screening for silvipastoral systems and animal performance and behaviour under trees.
\end{abstract}

A.C. Varella, Eng. Agr. (Ph. D.) ( $\square)$

Brazilian Agricultural Research Corporation (EMBRAPA), South Livestock Center (CPPSUL), BR 153, Km 603, 242, 96401-970 Bage, RS, Brazil e-mail: alexandre.varella@embrapa.br

J.L.S. da Silva, Eng. Agr. (D.Sc.)

EMBRAPA Temperate Climate (CPACT),

R.S. Barro, Eng. Agr. (D.Sc.)

J.C. de Saibro, Eng. Agr. (Ph. D.)

Faculty of Agronomy, Plant Forages Department,

Federal University of Rio Grande do Sul (UFRGS),

7712 Bento Goncalves Ave., 91540-000 Porto Alegre,

RS, Brazil

e-mail: raquelbarro@gmail.com;

jnsaibro@terra.com.br

403, Rodovia BR-392, Km 78, $9^{\circ}$ Distrito, Monte

Bonito, 96010-971 Pelotas, RS, Brazil

e-mail: jamir.silva@embrapa.br

V. Porfírio-da-Silva, Eng. Agr. (D.Sc.)

EMBRAPA Forestry (CNPF),

$319 \mathrm{~km}$ 111, Estrada da Ribeira, Bairro Guaraituba,

83411-000 Colombo, PR, Brazil

e-mail: vanderley.porfirio@embrapa.br

(C) Springer International Publishing Switzerland 2016

P.L. Peri et al. (eds.), Silvopastoral Systems in Southern South America,

Advances in Agroforestry 11, DOI 10.1007/978-3-319-24109-8_10 
Finally, the chapter analyses the existent opportunities to increase silvopastoral areas in southern Brazil and future challenges for research, development and technology transfer.

Keywords

Southern Brazil • Agroforestry $\bullet$ Tree $\bullet$ Forage $\bullet$ Cattle $\bullet$ Sheep

\subsection{Introduction}

The "cold zone" in Brazil is located in the southern region of the country, between latitudes $24^{\circ} \mathrm{S}$ and $33^{\circ} \mathrm{S}$, comprising the states of Rio Grande do Sul, Santa Catarina and the south-central region of Paraná, occupying an area of approximately $576,410 \mathrm{~km}^{2}$ (6\% of the national territory). This region has two important Biomes: the Pampa located at the most southern part of Rio Grande do Sul and the Atlantic Forest in southern Brazil territory. The climate is classified as subtropical cold with frequent frosts in winter and hot summers. Average annual temperatures range from 12 to $20{ }^{\circ} \mathrm{C}$ with well-defined seasons, and the annual average rainfall varies from 1250 to $2000 \mathrm{~mm}$ well distributed throughout the year. In the cold zones of Brazil, adaptation to frosts is the most important plant survival factor. As the frosts may vary each year (Fig. 10.1), the time of occurrence of frosts is critically important with regard to development of vegetation. The most damaging are early frosts in autumn and late spring. They eventually reach plants that are not cold hardy. In southern Brazil, 200,355 $\mathrm{km}^{2}$ are arable land, 48,430 $\mathrm{km}^{2}$ cultivated pastures, $108,426 \mathrm{~km}^{2}$ grasslands, $62,088 \mathrm{~km}^{2}$ natural forests and $25,313 \mathrm{~km}^{2}$ tree plantations. Of the total arable land, $87 \%$ is being used in row crop agriculture (i.e. soybean, maize and rice mainly) and $10 \%$ is devoted to fruits and horticulture and $3 \%$ to cutting forages (IBGE 2006).

Brazil has the second largest forest cover in the world, equivalent to $14.5 \%$ of the global forest area, surpassed only by Russia (FAO 2014). Out of the total area of the country (845.7 $\mathrm{M}$ ha= million ha), approximately $54.4 \%$ are covered by native forest and only $0.8 \%$ with plantations. Planted forests in Brazil occupy approximately
7.2 $\mathrm{M}$ ha, of which about 5.1 $\mathrm{M}$ ha are eucalyptus, 1.6 $\mathrm{M}$ ha pines, and $0.5 \mathrm{M}$ ha other species (ABRAF 2010). According to the Brazilian Association of Planted Forest Producers (ABRAF), the southern region currently has 1.9 million ha of eucalyptus (Eucalyptus spp.), pine (Pinus spp.), and black wattle (Acacia mearnsii) plantations and 511,000 ha of agroforestry areas (IBGE 2006). Among the main products of the national forest industry, the cold region of Brazil has a great emphasis on the production of yerba mate (Ilex paraguariensis), firewood, sawmill logs and wood for the panel, pulp and paper industries, besides the black wattle bark for tannin extraction.

This puts Brazil in a strategic position in global environmental issues due to the great productive potential of timber and non-timber forest products. From 1967 to 1987, reforestation programs with tax incentives resulted in a staggering growth in the sector, allowing organization of activities and consolidation of the forest sector as of great importance to the country. Investments, which totaled about US\$ 10 billion, according to the Brazilian Ministry of Environment (MMA), resulted in a surplus in the supply of wood during this period, as a result of significant technological development attained by the planted forest sector, raising productivity in plantations of pine and eucalyptus from 20 to $40 \mathrm{~m}^{3}$ per hectare per year.

With the end of tax incentives in 1987 , there was a drastic reduction in forest plantations, compromising the expansion of the sector and leading to a mismatch between timber supply and demand to meet the needs of projected growth by forest-based industry in the medium and long term. According to estimations of the Federal Government agencies and the Brazilian Society of Silviculture (SBS), Brazil will need about 275 


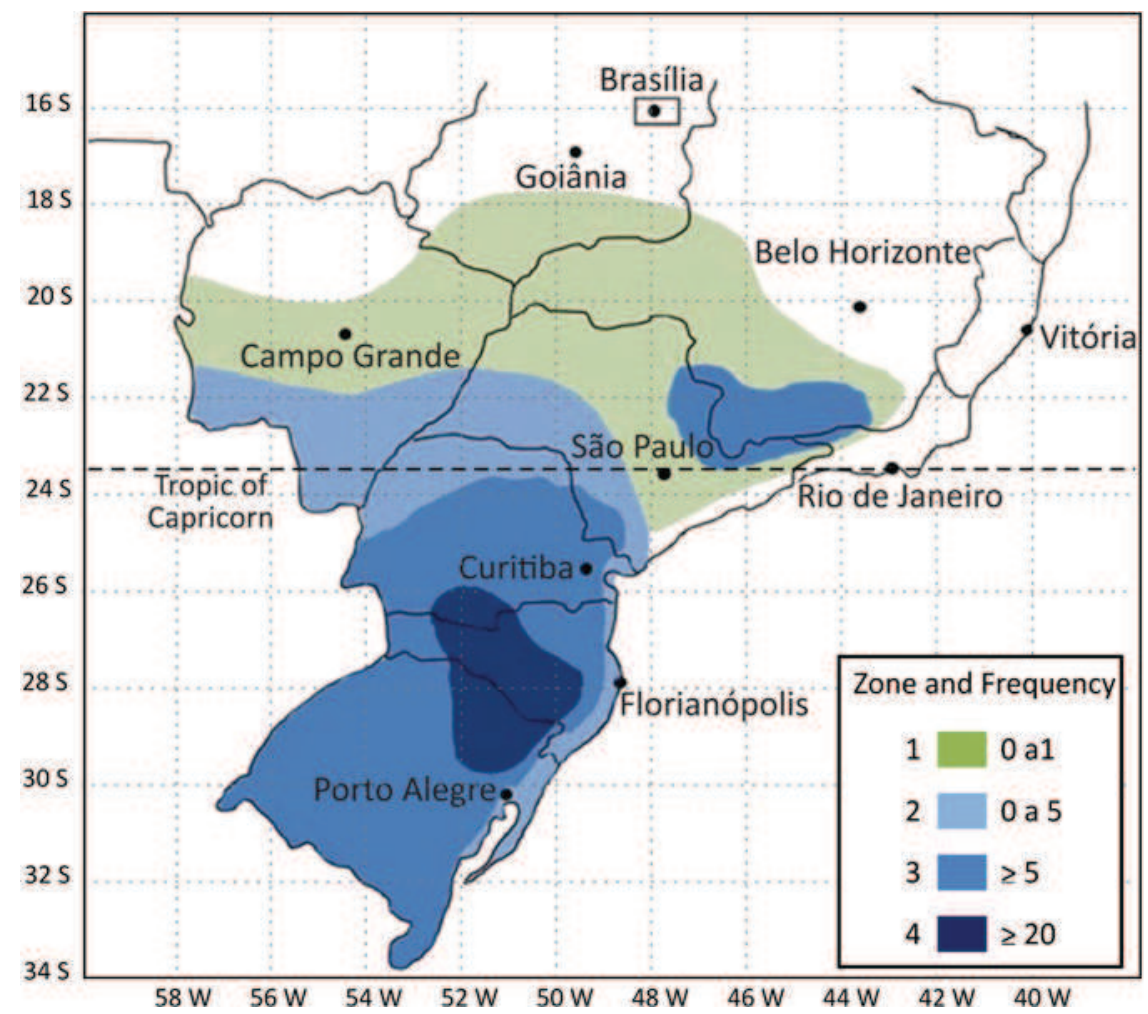

Fig. 10.1 Cold zones and frequency of frosts in southern Brazil. Data are from historical averages (Adapted from Sentelhas and Angelocci 2012)

million $\mathrm{m}^{3}$ of wood from planted forests by 2020 to meet the national demands of the pulp and paper, lumber, panels, charcoal and firewood industries. This means an estimated area of $8.7 \mathrm{M}$ ha to reach future demand of wood in the country by 2020, according to SBS (2008) and MMA. As southern Brazil concentrates $33 \%$ of the national forest planted forests, then RS, SC and PR states would need to increase from current $1.9 \mathrm{M}$ ha (IBGE 2006) to $2.9 \mathrm{M}$ ha by 2020 or about 71,000 ha per year from 2006 to 2020. The scenario also pointed out a marked imbalance between supply and demand, with imminent risk of a deficit in wood supply and negative consequences to primarily sawmills and the furniture industry. The crisis of wood from commercial forests, known as a national "forest blackout," strongly affected the forest industries. Therefore, since 2004, government new incentives through extensive credit and low interest rates were offered and a new cycle of expansion for planted forests occurred mainly with eucalyptus for the pulp and paper industries and pine for sawmill lumber and veneer in southern Brazil. Due to the favorable climate and soils, the high productive potential, the existence of high-tech production tools, the availability of land at a low acquisition cost and the simultaneous crisis of livestock and agricultural sectors in the early 2000s, national and international companies and producers increased the area of plantations by approximately 331,000 ha in the last 5 years, mainly with eucalyptus and black wattle on the border area with Uruguay, and pine in highland areas of the states of Rio Grande do Sul and Santa Catarina.

From the early 1990s, the increase in production costs (especially agricultural inputs), a decrease of native forest cover, an increase of degraded areas mainly through soil erosion consequent to an increase in agricultural activities and livestock operations, and the phenomenon of rural exodus and concerns about animal welfare, led to the search for new and more sustainable production systems in southern Brazil, particu- 
larly involving the integration of forestry with agriculture and livestock systems. As a result, the first agroforestry systems were initiated in southern Brazil. According to Radomski and Ribaski (2010), Paraná was the first State to use silvopastoral systems to any great extent, mainly on beef cattle farms. The Grevillea tree (Grevillea robusta) and species of Eucalyptus and Corymbia (Corymbia citriodora) represented the most common forest species identified in these systems. Associations between Eucalyptus and Grevillea with native trees such as Canafistula (Peltophorum dubium), Gurucaia (Parapiptadenia rigida), Guabiroba (Campomanesia sp.), Aroeira (Schinus terebinthifolius) and the Yellow Ipe (Tabebuia vellosoi) were also observed.

In the early 1990s, technical work involving agroforestry systems in the cold region of Brazil was begun, mainly from collaboration between research teams of Embrapa (the Brazilian Research Corporation), federal universities, southern states research institutes and the rural extension and technical assistance organizations. Also in the 1990s, several undergraduate and graduate courses such as Forestry, Agronomy, Animal Husbandry and Veterinary Science, as well as polytechnics and technical schools included in their academic curricula knowledge and training on agroforestry systems. In addition, between 1980 and 1994, 76 technical and scientific articles were published by workers at the southern research institutes, of which $70 \%$ were on agrosilvicultural systems and $30 \%$ on silvopastoral systems (Montoya et al. 1994). Also in the 1990s, the first Theses and Dissertations on agroforestry systems from federal universities in southern Brazil were published, allowing the formation of new knowledge and specialized human resources in this area.

Also since 2000, the technical and scientific experiences in agroforestry systems have multiplied in southern Brazil, especially with the work of scientists at Embrapa National Forestry Center (CNPF) and Sheep and Animal Husbandry Southern Center (CPPSUL), the Federal Universities of Rio Grande do Sul (UFRGS) and Paraná (UFPR), the Agricultural Research Foundation of Rio Grande do Sul (FEPAGRO), the Agricultural Research and Rural Extension
Institute of Santa Catarina State (EPAGRI), the Agronomic Institute of Paraná (IAPAR) and at Technical Assistance and Rural Extension Corporations of Rio Grande do Sul and Paraná States (EMATER/RS and EMATER/PR). Among the most common and relevant topics observed in these studies were: tolerance of forage and agricultural species to shading; indication of timber and non-timber tree species for agroforestry systems; forest spacing and planting designs for agroforestry; tree productivity, interaction between trees, understory plants and grazing animals (cattle and sheep) in the systems; economic, environmental and social aspects of agroforestry; microclimate, water and nutrient relations within the systems; carbon balance and emission of greenhouse gases.

Another relevant observation in the past decade was the involvement of the private sector, mainly from the pulp and paper industries, with scientific and technical activities on agroforestry systems in cold regions of Brazil. The opportunity to increase plantation area, the regional culture on singular cropping or extensive livestock systems, and the increasing concerns about environmental issues, motivated forestry companies to initiate technical and financial collaboration with research institutions and extension to conduct applied research on the integration of forest-agriculture-livestock systems. In addition, from 2004, forestry companies started promoting partnerships with the State Government of Rio Grande do Sul and credit financial institutions to expand agroforestry areas using eucalyptus and several crops and forages in southern Brazil. It was during this period that the greatest increase in agroforestry planted area in southern Brazil occurred, estimated at 3 million hectares currently. These areas mainly involved the combination of eucalyptus with various agricultural crops (soybean [Glycine max], maize [Zea mays], sorghum [Sorghum bicolor], sunflower [Helianthus annuus], watermelon [Citrullus lanatus], wheat [Triticum spp.], barley [Hordeum vulgare]) with forage species grown (annual ryegrass [Lolium multiflorum], oats [Avena spp.], white clover [Trifolium repens], red clover [Trifolium pratense], birdsfoot trefoil [Lotus cornicuatus]), and ruminant animals (Fig. 10.2).

Models of integrating trees with agriculture and livestock, promoted by forestry companies in 

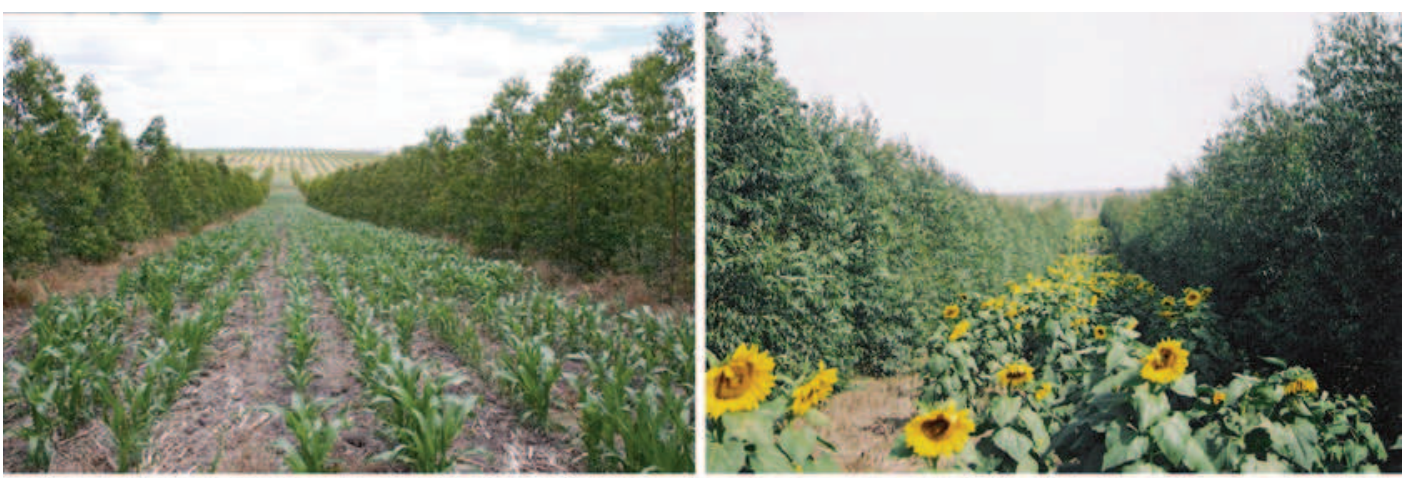

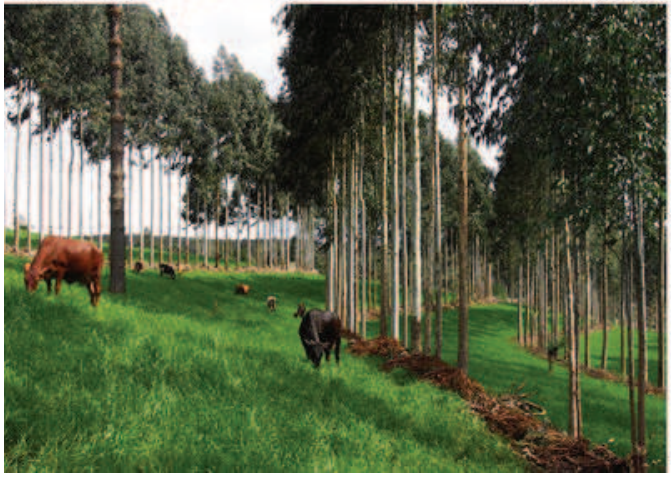

Fig. 10.2 Agroforestry systems used in southern Brazil: integration between eucalyptus and sorghum [Sorghum bicolor] at VCP Company (above and left), sunflower [Helianthus annuus] (above and right); integration between eucalyptus (Eucalyptus grandis), tropical grass (Brachairia

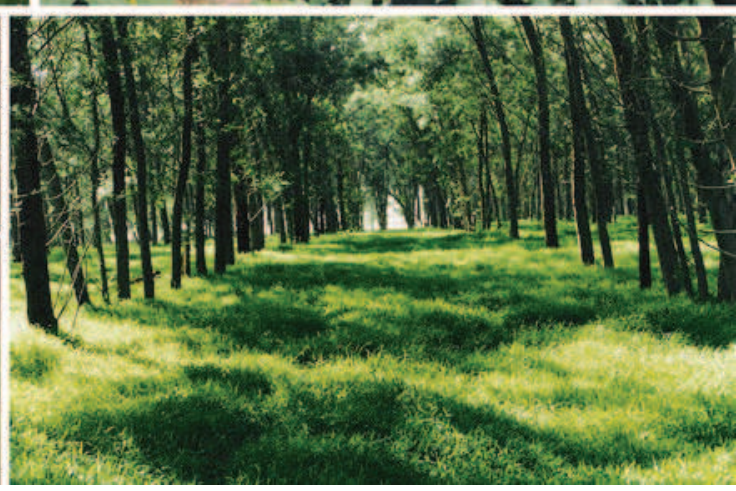

brizantha), eucalypt, grass temperate pasture and beef cattle at a smallholder property in Paraná State (below and left) and integration between black wattle and Digitaria diversinervis grass at FEPAGRO (below and right) (Images from: A.C. Varella; V. Porfirio-da-Silva; Z.M. Castilhos)

ing grazing only in the border areas. This fact has discouraged many farmers and producers from Rio Grande do Sul, who considered that this model would turn their traditional animal production systems into conventional forestry rather than long-term integration systems. In 2010, the forest development programs were discontinued in southern Brazil because forest companies and environmentalists disagreed about environmental issues raised by the government of Rio Grande do Sul that were aimed at permitting establishment of more plantations. Also the lack of firm positioning from State Government for the consolidation of forestry sector in southern Brazil discouraged advances in forestry investments. These factors caused forest companies to revise their strategic plans, quit the expansion of forestry and agroforestry areas, particularly in Rio Grande do Sul, and change their investments to the tropical and central region of Brazil. years after trees had been planted. Then the area turned into an exclusive forest plantation, allow- 
Conversely, forestry investments were maintained similarly in Santa Catarina and Parana over the last 5 years. In these States, agriculture is predominant and area for expansion of conventional forestry investments is limited, nevertheless there is still land area for the expansion of agroforestry systems.

The situation will likely remain the same in the near future. The southern region of Brazil will experience a decrease in the supply of raw material for forest products, particularly to meet the demands of the furniture industry, sawn wood, medium density fiberboard (MDF) and particleboard, joinery and carpentry business, pulp and paper industry, tannins, resins, and chemicals derived from black wattle, posts and treated wood for construction, and wood for energy and charcoal. New debates for the resumption of forestry investments returned to the public agenda of governments, forestry managers, technicians, producers and more recently companies. This time, trying to establish a new strategy based on territorial and sustainable development, as required by a modern society, with production systems adapted to the environmental, cultural and productive conditions of the southern region. Clear rules and better integration for negotiating parties (government, environmentalists, farmers and companies) are needed to set a new cycle of forestry and agroforestry growth in southern Brazil. Therefore, agroforestry systems may provide a sustainable alternative to all parties, leading to new challenges for stakeholders and encourage the return of investments and expansion of agroforestry area in southern Brazil by private sector. To achieve that objective, some challenges must be addressed:

- Proposition of feasible models for forestrylivestock farming systems in contrast to the traditional agricultural cultivation, the extensive cattle and sheep rangeland systems and the specialization of forestry systems commonly used on farms and by companies in southern Brazil;

- Implementation of new programs promoting agroforestry, integrating public and private sector and encouraging the establishment of low tree density (below 800 trees/ha) systems and offering financial credit compatible with the length of time required to obtain wood in these systems. Forest companies should change their strategy and focus on increasing the planting area (suppliers) by attracting more farmers (mostly rangeland producers) with the proposition to establish integrated systems. Animal producers are generally resistant to conversion of rangeland systems to a long-term profit system such as forestry plantations;

- Reversal of the current situation of little knowledge and appreciation for the role of trees in farming systems (commercial, environmental, animal welfare, landscape) by reinforcing curricula in schools and universities;

- To implement public policies that support a strategy of territorial management using geospatial tools (satellite imagery and georeferenced information system) capable of supporting decisions and rules for forestry and agroforestry business and reducing environmental concerns, particularly avoiding exceeded occupation of natural biomes in southern Brazil;

- Enhance the certification of forest products from sustainable systems such as agroforestry;

- Create massive technical training programs on agroforestry systems in the public and private sectors, associated with consulting firms, official technical assistance, rural extension, and cooperatives.

This chapter includes main results collected from agroforestry experiments in Rio Grande do Sul, Santa Catarina and Parana, including several $\mathrm{C}_{3}$ and $\mathrm{C}_{4}$ pastures (natives and exotics) performances under shade, beef cattle and sheep performance and behaviour under trees, climate-tree-pasture-animal interactions, and other relevant results from the last 20 years. As part of this challenge, this chapter aims to: (i) review the major scientific and technological advances in silvopastoral systems, with emphasis on silvopastoral systems developed by public and 
private institutions in southern Brazil; (ii) Report success cases from producers and forestry companies; (iii) propose alternatives for expanding the area of silvopastoral systems in southern Brazil in order to promote development with sustainable land management and providing opportunities to many services and multifunctional activities in farms, benefiting producers, industry and consumers involved in this chain.

\subsection{Potential of Forage Plants for Silvopastoral Systems in Southern Brazil}

The focus of research on silvopastoral systems in the late 1990s was to conduct experiments based on reductionist models, aiming to study binary interactions between the components of the integrated system, such as tree-pasture, soil-plant, plant-environment, etc. (Saibro 2001) and rarely contemplated the effect of the grazing animals (Saibro and Barro 2009).

Since then, a series of silvopastoral projects were developed with grasslands, which is an important and remarkable forage resource in the southern region of Brazil, particularly in Rio Grande do Sul State. These studies demonstrated that tree species, age, and density are factors that interfere with the growth of $\mathrm{C}_{3}$ and $\mathrm{C}_{4}$ species of the native grasslands. This occurs because of changes in light quantity and quality that passes through the trees. For example, Varella and Saibro (1999) found no differences on dry matter yield underneath three Eucalyptus saligna densities (816, 400 and 204 trees ha-1) in the first and second years of a silvopastoral system at the experimental site of UFRGS. According to the author, the incident radiation was not limiting to understory vegetation because trees were approximately $2 \mathrm{~m}$ in height in this experiment. In addition, Fucks (1999), working at the same experimental site, reported decreases on grazing days, dry matter yield and stocking rates under the tree densities at years 3 and 4. In another UFRGS experiment, Silva (1998), working with winter pasture under E. saligna, reported that tree density influenced animal performance as pasture density and carrying capacity decreased, affecting beef cattle gains after the second year of tree establishment.

In the past, several studies focused on quantifying the effects of reduced radiation on the yield of understory pasture, seeking to determine limits of pasture growth and forage shade tolerance when altering tree densities. In these experiments, the shading levels were usually high after the second and third year as a consequence of the high tree populations established (800-1000 trees $\mathrm{ha}^{-1}$ ), using fast growing trees and simple rows arrangement (Schreiner 1987; Silva et al. 1998; Fucks 1999; Varella and Saibro 1999; Lucas 2004). Despite these important advances, research on silvopastoral systems faced a discontinuation of support by financial agencies in the Brazilian subtropics and studies with a sequence of tree-pasture interactions in experimental sites were missed at that stage. Therefore, there is still lack of scientific information on pasture yield and management of silvopastoral system over the complete productive cycle of silvopastoral systems, particularly underneath fast growing tree species such as Eucalyptus sp. and Pinus sp.

The next step in silvopastoral research in southern Brazil was the investigation of the changes on pasture morphology, physiology, and nutritive value in response to shading, from the early 2000s (Barro et al. 2008; Soares et al. 2009). More recently, important scientific advances have been made in understanding the mechanisms of pasture adaptation and tolerance to shading from research groups in southern Brazil (Varella et al. 2011; Barro et al. 2012; Pontes et al. 2014; Baldissera et al. 2014). For instance, Pontes et al. (2014) and Baldissera et al. (2014) showed the relationship between soil N supply, plant height and light interception of six perennial tropical forages under trees, leading to important management practices of pasture intensity for silvopastoral systems. In addition, Barro et al. (2012) showed the N nutrition dynamics and forage yield of four important forages from southern grasslands in Brazil under shading and potential to use them in silvopastoral systems. This meant an extra step to better establish and manage pastures underneath trees and conse- 
quently, increase pasture productivity and quality in integrated systems.

The preliminary results indicated that more conservative management of pasture under shade has greater chances of success (longevity, yield, and quality) (Baldissera 2014). Overall, the management of understory pastures requires continuous investigation on silvopastoral systems in order to generate growth models as a function of available solar radiation and management applied. This would support pasture and grazing management decisions by farmers as trees develop in the system.

\subsubsection{Overview of Forage Research in Shaded Environments}

Grazing management can be established by controlling the frequency and intensity of defoliation (Pedreira et al. 2007). The combination of these variables greatly affects the structure of the pasture canopy (Da Trindade et al. 2007), which are also influenced by shading. However, only recently basic investigations concerning the influence of grazing management on shaded pastures and morphophysiological changes have been conducted in southern Brazil.

In agroforestry systems, grazing management should explore the phenotypic plasticity of forage species under shade. Scientists have recommended that forages under shade should be managed in order to maintain more residual leaf area or post-grazing heights greater than those in full sun. However, further studies on frequency and intensity of grazing pastures are required in silvopastoral systems, along with studies of pasture nutrient and water efficiencies in order to develop better pasture management strategies.

The interception of photosynthetically active radiation (iPAR) by the pasture canopy is the main variable used for determining the optimal timing for grazing defoliation (Silva and Carvalho 2005). In full sunlight, $95 \%$ light interception by the pasture canopy results in optimum growth (Silva and Carvalho 2005; Da Trindade et al. 2007). Thus, consistent relationships between sward height on pre-grazing and iPAR by the canopy has being determined for several forage species in full sun (e.g. Zanini et al. 2012; Amaral et al. 2013), but rarely under shaded conditions. Finally, it has been pointed that this relationship may be different in silvopastoral systems than in open pastures as canopy photosynthesis decreases rapidly under shade and less carbon reserves are stored in roots (Barro et al. 2012; Varella et al. 2012). Therefore, more research also needs to be conducted to determine the optimum light interception point by pasture canopies under shade for cutting or grazing.

\subsubsection{Perennial $C_{4}$ Forages}

The adaptation of perennial forages to different levels of shading has been a target of many studies in Brazil for at least 20 years (e.g. Schreiner 1987). In the cold regions of the subtropics, tropical perennial forages stop growing during autumn and winter seasons and, eventually, susceptible genotypes are unable to survive over the frosty period in southern Brazil. The silvopastoral integration allows obtaining productive perennial $\mathrm{C}_{4}$ pastures all year by minimizing climate extremes under the trees (Lucas 2004; Sartor et al. 2006; Kirchner et al. 2010). Even in the coldest areas of southern Brazil, where severe frosts are frequent from April to August, tropical pastures such as Brachiaria spp., Panicum spp. and Cynodon spp. can remain green and productive for longer periods under trees than they would tolerate in an open area (Fig. 10.3) and this represents an extraordinary feeding resource for cattle and sheep during extreme weather on farms.

Several studies have shown the potential yield of tropical forages under moderate shade in southern Brazil (Table 10.1). Research has shown the best growth responses, morphological and physiological adaptation and nutritive value of $\mathrm{C}_{4}$ grasses under moderate shade (up to $40-50 \%$ shading). In some cases, the shading effect may be very beneficial, resulting in higher dry matter yields compared to open pastures, especially in soil water and nitrogen deficit conditions, 


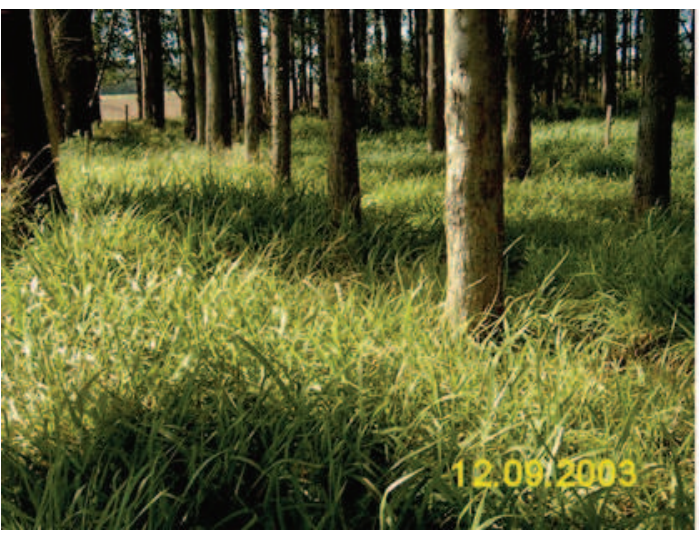

Fig. 10.3 Experiment evaluation of Panicum maximum under Eucalyptus spp. (left side) and in full sun (right side) at FEPAGRO Unit in Rio Grande do Sul. Photos

depending on tree density and type of soil. For example, recent studies have shown the unique response of Paspalum regnellii (Table 10.1), highlighting its potential yield under severe shading (up to $80 \%$ shade) and the improvement of forage nitrogen content (Barro et al. 2012). As shown in Table 10.1, the study of $\mathrm{C}_{4}$ perennial forages under shade is highlighted in southern Brazil because of the potential of early production in spring after the second year of establishment and high growth rates in summer when native and annual pastures are usually water stressed. Also, perennials are preferred by farmers over annual pastures for silvopastoral systems as the process of germination and emergence are difficult in shaded environments and pasture production costs are higher (Varella et al. 2011).

In addition to $P$. regnellii, other native grasses from Pampa and Atlantic Forest Biomes have shown potential for use in shaded environments. These species were initially identified at the transitional area between native forests and grasslands of southern Brazil, such as $P$. regnellii (Barro et al. 2012), Axonopus catharinensis (Soares et al. 2009; Barro et al. 2008) as well as forage species from open sites which showed high plasticity under shade, such as Paspalum notatum (Soares et al. 2009), P. dilatatum (Barro et al. 2012) and Arachis pintoi (Barro et al. 2014). However, further research advances with these

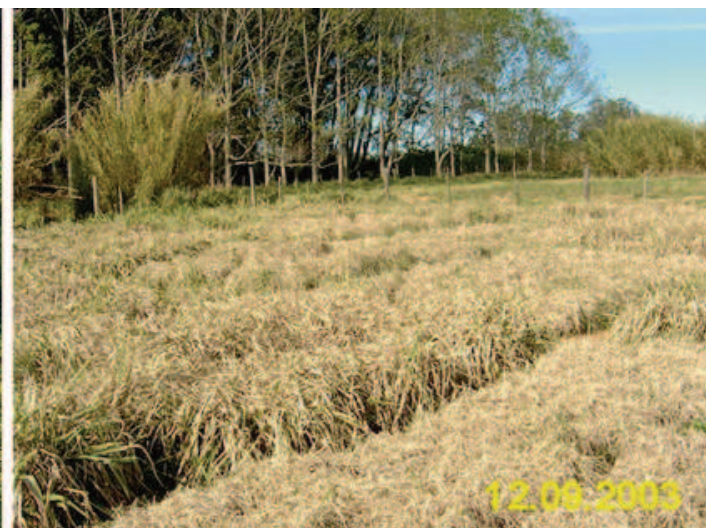

were taken at the same moment after a severe frosting event on September, 12th 2003 (Images from J. C. Saibro)

perennial native forages, particularly evaluation under grazing, have faced difficulties because of the lack of seed of commercial cultivars in the market. Research institutions are putting great efforts into getting registration of these native forage cultivars by the Brazilian Ministry of Agriculture, Livestock and Food Supply and to establish seed fields of these cultivars to enable farmers to increase silvopastoral systems based on $\mathrm{C}_{4}$ pastures.

\subsubsection{Annual and Perennial $C_{3}$ Forages Adapted to Shade}

Besides the perennial $\mathrm{C}_{4}$ grasses, the animal production systems in southern Brazil are characterized by the cultivation of winter forage grasses. The most commonly grown pasture species used are annual ryegrass (Silva et al. 1998; Barro et al. 2008; Kirchner et al. 2010), forage oats(Deiss et al. 2014) and the dual purpose cereals (wheat, barley, triticale and oats). Currently, these species are objects of research in various institutions (Table 10.2), in different production systems, with or without the presence of trees and with the possibility of being used in rotational systems, particularly with cash crops (soybean and maize) over the summer or composing an agroforestry system. 
Table 10.1 Summary of $\mathrm{C}_{4}$ pastures tolerance to shade from several studies in southern Brazil

Relative yield

\begin{tabular}{|c|c|c|c|c|c|c|c|c|}
\hline Forage cicle & $\begin{array}{l}\text { Carbon } \\
\text { fixation }\end{array}$ & $\begin{array}{l}\text { Growing } \\
\text { season }\end{array}$ & Species & Shade level tested & Type of shading & $\begin{array}{l}\text { Relative yield } \\
\text { to full sun }\end{array}$ & Effect on nutritive value & References \\
\hline & & & \multirow[t]{3}{*}{ Axonopus catharinensis } & 24 and $56 \%$ & Tree shade & 52 and $50 \%$ & Not determined & Barro et al. (2008) \\
\hline & & & & 17 and $33 \%$ & Tree shade & 79 and $47 \%$ & Increased & Soares et al. (2009) \\
\hline & & & & 40 to $50 \%$ & Tree shade & $74 \%$ & Not determined & Pontes et al. (2012) \\
\hline & & & \multirow{3}{*}{$\begin{array}{l}\text { Cynodon sp. } \\
\text { (cv.Tifton 85) }\end{array}$} & 40 to $50 \%{ }^{\mathrm{a}}$ & Tree shade & 25 and $50 \%$ & Not determined & Pontes et al. (2012) \\
\hline & & & & 24 and $56 \%$ & Tree shade & 61 and $51 \%$ & Not determined & Barro et al. (2008) \\
\hline & & & & 17 and $33 \%$ & Tree shade & 48 and $24 \%$ & Increased & Soares et al. (2009) \\
\hline & & & \multirow{2}{*}{$\begin{array}{l}\text { Brachiaria brizantha } \\
\text { cv Marandu }\end{array}$} & 17 and $33 \%$ & Tree shade & 86 and $36 \%$ & Increased or mantained & Soares et al. (2009) \\
\hline & & & & 40 to $50 \%$ & Tree shade & $45 \%$ & Not determined & Pontes et al. (2012) \\
\hline & & & $\begin{array}{l}\text { Brachiaria decumbens } \\
\mathrm{cv} \text {. Basilisk }\end{array}$ & 17 and $33 \%$ & Tree shade & 48 and $24 \%$ & Not determined & Soares et al. (2009) \\
\hline & & & Brachiaria decumbens & 25,50 and $80 \%$ & Artificial shade & 85,44 and $22,7 \%$ & Not determined & Schreiner (1987) \\
\hline & & & Digitaria decumbens & 25,50 and $80 \%$ & Artificial shade & 88,60 and $25 \%$ & Not determined & Schreiner (1987) \\
\hline & & & Panicum maximum cv. & 17 and $33 \%$ & Tree shade & 54 and $9 \%$ & Increased & Soares et al. (2009) \\
\hline & & & Aruana & 40 to $50 \%{ }^{\mathrm{a}}$ & Tree shade & 57 and $20 \%$ & Not determined & Pontes et al. (2012) \\
\hline \multirow[t]{14}{*}{ Perennial } & \multirow[t]{14}{*}{$\mathrm{C} 4$} & \multirow[t]{14}{*}{ Summer } & \multirow{2}{*}{$\begin{array}{l}\text { Panicum maximum cv. } \\
\text { Tanzânia }\end{array}$} & 17 and $33 \%$ & Tree shade & 61 and $0 \%$ & Not determined & Soares et al. (2009) \\
\hline & & & & not determined & Tree shade & $25 \%$ & Not determined & Ferreira et al. (2006) \\
\hline & & & \multirow{2}{*}{$\begin{array}{l}\text { Panicum maximum cv. } \\
\text { Mombaça }\end{array}$} & 17 and $33 \%$ & Tree shade & 47 and $15 \%$ & Not determined & Soares et al. (2009) \\
\hline & & & & not determined & Tree shade & $22 \%$ & Not determined & Lucas (2004) \\
\hline & & & \multirow{3}{*}{$\begin{array}{l}\text { Paspalum notatum cv. } \\
\text { Pensacola }\end{array}$} & 17 and $33 \%$ & Tree shade & 87 and $26 \%$ & Not determined & Soares et al. (2009) \\
\hline & & & & 40 and $50 \%$ & Tree shade & 54 and $10 \%$ & Not determined & Pontes et al. (2012) \\
\hline & & & & 25,50 and $80 \%$ & Artificial shade & 93,55 e $13 \%$ & Not determined & Schreiner (1987) \\
\hline & & & Paspalum notatum & 50 and $80 \%$ & Artificial shade & 112 and $81 \% \mathrm{a}$ & Increased & Barro et al. (2012) \\
\hline & & & Paspalum dilatatum & 50 and $80 \%$ & Artificial shade & 117 and $81 \%$ & Increased & Barro et al. (2012) \\
\hline & & & Paspalum regnelii & 50 and $80 \%$ & Artificial shade & 118 and $99 \%{ }^{\mathrm{a}}$ & Increased & Barro et al. (2012) \\
\hline & & & Hemarthria altissima & 25,50 and $80 \%$ & Artificial shade & 99 and $22 \%$ & Not determined & Schreiner (1987) \\
\hline & & & \multirow{3}{*}{$\begin{array}{l}\text { Hemarthria altissima cv. } \\
\text { Flórida }\end{array}$} & 17 and $33 \%$ & Tree shade & 66 and $5 \%$ & Not determined & Soares et al. (2009) \\
\hline & & & & 40 to $50 \%$ & Tree shade & $7 \%$ & Not determined & Pontes et al. (2012) \\
\hline & & & & 24 and $56 \%$ & Tree shade & 58 and $43 \%$ & Not determined & Barro et al. (2008) \\
\hline
\end{tabular}

${ }^{a}$ Under severe drought 
Table 10.2 Summary of $C_{3}$ pastures tolerance to shade from several studies in southern Brazil

\begin{tabular}{|c|c|c|c|c|c|c|c|c|}
\hline Forage cicle & $\begin{array}{l}\text { Carbon } \\
\text { fixation }\end{array}$ & $\begin{array}{l}\text { Growing } \\
\text { season }\end{array}$ & Species & Shade level & Type of shading & $\begin{array}{l}\text { Relative yield to } \\
\text { full sun }\end{array}$ & Effect on nutritive & References \\
\hline & & & & 30 e $60 \%$ & Tree shade & 43 and $22 \%$ & Increased & Kirchner et al. (2010) \\
\hline & & & Lolium multiflorum & 24 and $56 \%$ & Tree shade & 46 and $36 \%$ & Increased & Barro et al. (2008) \\
\hline & & & & 33 and $58 \%$ & Artificial shade & 87 and 84 & Not determined & Saibro $(1992)^{\mathrm{a}}$ \\
\hline & & & & 30 e $60 \%$ & Tree shade & 38 and $13 \%$ & Increased & Kirchner et al. (2010) \\
\hline & & & Avena sativa & 24 and $56 \%$ & Tree shade & 75 amd $42 \%$ & $\begin{array}{l}\text { Increased or } \\
\text { mantained }\end{array}$ & Barro et al. (2008) \\
\hline \multirow[t]{8}{*}{ Annual } & \multirow[t]{8}{*}{$\mathrm{C} 3$} & \multirow[t]{8}{*}{ inverno } & \multirow[t]{2}{*}{ Avena strigosa } & 30 and $60 \%$ & Tree shade & 43 and $8 \%$ & Piora & Kirchner et al. (2010) \\
\hline & & & & 24 and $56 \%$ & Tree shade & 75 and $42 \%$ & Decreased & Barro et al. (2008) \\
\hline & & & Holcus lanatus & 50 and $80 \%$ & Artificial shade & 234 and $223 \%^{a}$ & Not determined & Varella et al. (2008) \\
\hline & & & Bromus auleticus & 50 and $80 \%$ & Artificial shade & 737 and $605 \%^{a}$ & Not determined & Varella et al. (2008) \\
\hline & & & Bromus catharticus & 50 and $80 \%$ & Artificial shade & 205 and $159 \%^{\mathrm{a}}$ & Not determined & Varella et al. (2008) \\
\hline & & & Triticum aestivum-duplo proposito & 30 and $60 \%$ & Tree shade & 46 and $25 \%$ & Decreased & Kirchner et al. (2010) \\
\hline & & & Vicia villosa & 30 and $60 \%$ & Tree shade & 48 and $27 \%$ & Mantained & Kirchner et al. (2010) \\
\hline & & & Arachis Pintoi (hybrid ecotype) & 50 and $80 \%$ & Artificial shade & 93 and $60 \%$ & Decreased & Barro et al. (2014) \\
\hline \multirow[t]{2}{*}{ Perennial } & $\mathrm{C} 3$ & verão & Arachis pintoi cv. Alqueire & 17 and $33 \%$ & Tree shade & 37 and $18 \%$ & Not determined & Soares et al. (2009) \\
\hline & & & Arachis pintoi cv. Amarillo & 17 and $33 \%$ & Artificial shade & 59 and $23 \%$ & Not determined & Soares et al. (2009) \\
\hline \multirow[t]{2}{*}{ Perennial } & \multirow[t]{2}{*}{$\mathrm{C} 3$} & \multirow[t]{2}{*}{ inverno } & Trifolium repens cv. Zapicân & 24 and $56 \%$ & Tree shade & 25 and $40 \%$ & Decreased & Saibro et al. (2008) \\
\hline & & & Lotus comiculatus cv. São Gabriel & 24 and $56 \%$ & Tree shade & 27 and $25 \%$ & Decreased & Saibro et al. (2008) \\
\hline
\end{tabular}

${ }^{\mathrm{a} U n d e r ~ s e v e r e ~ d r o u g h t ~}$ 
For this group of pastures, Porfirio-da-Silva (2012) found a decrease in forage yield in silvopastoral systems compared to full sun. For instance, the winter pastures Avena strigosa and A. sativa intercropped with Lolium multiflorum were evaluated in two integrated systems: with and without the presence of trees. Forage yield in full sun averaged $2524 \mathrm{~kg} \mathrm{DM} \mathrm{ha}{ }^{-1}$ and was higher than under shade which yielded $2210 \mathrm{~kg}$ $\mathrm{DM} \mathrm{ha}{ }^{-1}$. However, beef cattle liveweight gains were similar between the treatments, ranging from 0.55 to $1.10 \mathrm{~kg} \mathrm{LW} \mathrm{day}{ }^{-1}$. In addition, Kirchner et al. (2010) reported yields of several winter forages varying from 38 to $48 \%$ under $15 \times 3 \mathrm{~m}$ Pinus taeda system (30\% shade) and from 8 to $27 \%$ under $9 \times 3 \mathrm{~m}$ (60\% shading) compared to open pastures in Santa Catarina State. Likewise, annual ryegrass performance was highlighted in this study, yielding $3478 \mathrm{~kg}$ $\mathrm{DM} \mathrm{ha}^{-1}$ and showing $18 \%$ of total crude protein under the $15 \times 3 \mathrm{~m}$ system.

The responses of $\mathrm{C}_{3}$ legumes on DM yield and nutritive value are individual and dependent on their agronomic performance under shade. Results as to the quantitative and qualitative performance of winter forage legumes in single or mixture pastures and under different shading levels were obtained in the subtropics (Table 10.2). For example, white clover (Trifolium repens) and birdsfoot trefoil (Lotus corniculatus) yields were similar under $15 \times 3 \mathrm{~m}$ Pinus taeda system (moderate shading) compared to full sunlight (Barro et al. 2006) growing on a sandy soil of the coastal area in Rio Grande do Sul State. In a different experimental site, Sartor et al. (2006) reported that birdsfoot trefoil yielded 2844 and $2669 \mathrm{~kg}$ $\mathrm{DM} \mathrm{ha}^{-1}$ under the $15 \times 3 \mathrm{~m}$ and $9 \times 3 \mathrm{~m}$ Pinus taeda system, respectively, whereas in an open pasture yielded $8121 \mathrm{~kg} \mathrm{DM} \mathrm{ha}^{-1}$ on clay soil of Santa Catarina State. In sequence at the same experimental site, Kirchner et al. (2010) showed that the annual legume forage Vicia villosa yielded $2300 \mathrm{~kg} \mathrm{DM} \mathrm{ha}^{-1}$ under intermediate shade $(15 \times 3 \mathrm{~m})$ and $1292 \mathrm{~kg} \mathrm{DM} \mathrm{ha}^{-1}$ under the heavy shade $(9 \times 3 \mathrm{~m})$ compared to $4771 \mathrm{~kg} D M$ $\mathrm{ha}^{-1}$ in full sun. In artificial shade conditions, Barro et al. (2010) reported that Arachis pintoi yield was affected by intense shade ( $80 \%)$, but still showed potential to increase nutritive value of natural grass-legume mixtures under intermediate $(50 \%)$ shade level. Under intense shading (80\%), Arachis pintoi showed a decrease of $40 \%$ in dry matter yield compared to full sun. However, under moderate shading (50\%), this legume performance was not affected (Table 10.2).

The performance of forage legumes at different levels of radiation has shown that these are usually less shade tolerant than grasses (Watson et al. 1984; Barro et al. 2012), although this is not necessarily a rule (Johnson et al. 2002) and may change under soil nitrogen stress. The large, productive and reproductive success of forage legumes in agroforestry depends on their ability to adapt to decreasing levels of light with tree canopy closure with advancing age (Balocchi and Phillips 1997). Physiologically, the forage legumes operate as $\mathrm{C} 3$ plants, and could potentially support shading at intermediate levels. However, quite different responses have occurred with regard to the agronomic performance of forage legumes under shade. There is still inadequate scientific information regarding the performance of legumes under shade in subtropical environments of Brazil (Varella et al. 2009).

\subsection{Potential of Trees for Silvopastoral Systems in Southern Brazil}

The trees most commonly used in silvopastoral systems in cold regions of Brazil are species adapted to climate and soil conditions of the region, with relatively rapid growth rate (about $2 \mathrm{~m}$ high per year) and with great value of the wood in the market (Table 10.3). Historically the integration of beef cattle with forests date from the mid-eighteenth century (Chang 1985), known as traditional "faxinais" systems, mainly established in the area of occurrence of Araucaria native forests (Araucaria angustifolia). The first studies of silvopastoral systems in the Brazilian subtropics sought to utilize livestock as a secondary component of the system. Cattle were introduced in conventional tree plantations as a strategy to improve cash flow in the early years of 
Table 10.3 Predominant tree species applied in silvopastoral systems in cold zones of Brazil

\begin{tabular}{|c|c|c|}
\hline $\begin{array}{l}\text { Number of } \\
\text { frost events }\end{array}$ & $\begin{array}{l}\text { Tree species or hybrids used in silvipastoral } \\
\text { systems }\end{array}$ & Tree species tested in experimental studies \\
\hline \multirow[t]{2}{*}{$0-1$} & \multirow{2}{*}{$\begin{array}{l}\text { Eucalyptus urophylla; } \text { E. urophylla } x \text { E. grandis; } \\
\text { Corymbia citriodora; } \text { C. camaldulensis; }\end{array}$} & Tropical Pinus (Gutmanis 2004) \\
\hline & & $\begin{array}{l}\text { Native species (Melotto et al. 2009; } \\
\text { Nicodemo et al. 2010) }\end{array}$ \\
\hline \multirow[t]{3}{*}{$0-5$} & \multirow[t]{3}{*}{$\begin{array}{l}\text { E. grandis; } \text { E. urophyllax E. grandis } ; \text { C. citriodora; } \\
\text { C. camaldulensis; Grevillea robusta; }\end{array}$} & $\begin{array}{l}\text { Native species (Melotto et al. 2009; } \\
\text { Nicodemo et al. 2010) }\end{array}$ \\
\hline & & $\begin{array}{l}\text { Kaya ivorensis e Toona ciliata (Porfírio-da- } \\
\text { Silva et al. unpublished data) }\end{array}$ \\
\hline & & Leucaena spp. (Sampaio et al. 2009) \\
\hline \multirow[t]{3}{*}{$\geq 5$} & \multirow[t]{3}{*}{$\begin{array}{l}\text { E. dunnii; E. benthamii; Acacia mearsii; E. grandis; } \\
\text { E. saligna; Grevillea robusta; Araucaria angustifolia }\end{array}$} & $\begin{array}{l}\text { Native species (Radomski and Ribaski } \\
\text { 2010; Porfírio-da-Silva et al. 2012) }\end{array}$ \\
\hline & & Populus spp. (Otto et al. 2009) \\
\hline & & Pinus elliotti (Ribaski et al. 2005) \\
\hline$\geq 20$ & $\begin{array}{l}\text { E. benthamii; Pinnus taeda; } \text { P. elliottii; Araucaria } \\
\text { angustifolia }\end{array}$ & Pinus taeda (Soares et al. 2009) \\
\hline
\end{tabular}

forest cultivation, besides getting the benefits of controlling the development of unwanted plants in the understory and reducing the risks of fire inside the forest (Baggio and Schreiner 1988; Schreiner 1994; Varella and Saibro 1999; Silva et al. 2001).

Although there is potential for use of many other tree species, Eucalyptus spp. is the most commonly planted one in cold regions of Brazil, followed by Grevillea robusta (Martins et al. 2015), Acacia mearsii, and subtropical Pinus spp. The genus Eucalyptus is important for Brazil because of the raw material for pulp production, coal, wood, panels, posts, poles, sawn timber, furniture, packaging and other commercial uses. This tree species and its different cultivars are well adapted to southern Brazil conditions and can compose silvopastoral systems in almost all territories. In Zones 1 and 2 (Fig. 10.2), successful plantings have been carried out with hybrids between Eucalyptus grandis x E. urophylla; especially in the western portions of these zones, where frequent droughts can also occur during the summer and autumn seasons. Because of the rapid growth of these hybrids during the first spring and summer seasons, plants can tolerate the cold temperatures in the first winter period. $E$. grandis has been planted successfully in the southern portions of Zone 2 and north- northwest of Zone 3 (Higa and Wrege 2010), except on the coastal area where the species may be affected by various diseases caused by high relative humidity (Alfenas et al. 1983). The Corymbia citriodora and $C$. camaldulensis species has also been observed in silvopastoral systems across Zone 2, except at the coastal area where the tree-pasture systems are rare. The E. benthamii and E. dunnii are more tolerant to low temperatures and this is the main reason for them to be widely planted in silvopastoral systems of Zone 3. E. benthamii is the most tolerant species to frosts among all species of Eucalyptus sp. (Jovanovic and Booth 2002; Paludzyszyn Filho and Santos 2013) and has been planted in Zone 4. E. saligna also has been planted in integrated systems in this area (Silva 1998; Varella 1997). In addition to E. benthamii, subtropical species of pine (Pinus elliottii and $P$. taeda) have also been used for silvopastoral systems in Zone 4. These pines have also been planted in Zone 3 of southern Brazil.

In Brazil, soil and water conservation is a priority when planning the introduction of trees into pastures. This means that the orientation of the tree rows during system establishment must be a priority in order to promote soil and water conservation. Observation of the apparent path of the sun in the sky to orient the arrangement of tree rows is secondary to consideration of soil and water conservation issues. The solar energy that reaches the land in cold zones of Brazil is high, ranging from 4 to $6 \mathrm{~kW} \cdot \mathrm{hm}^{-2}$ (Ceballos and Bottino 2006). The region where the incidence of 
solar radiation is lowest $\left(4.5 \mathrm{~kW} \cdot \mathrm{hm}^{-2}\right)$ partially coincides with Zone 4 in Fig. 10.2, and it is distributed along to the coastline and nearby Itajai River valley, and this fact has been associated with increasing cloudiness in these regions.

The spatial arrangement of trees is critical for the success of a silvopastoral system. Establishment is facilitated by proper spatial distribution of trees in the field and this should aim to promote soil and water conservation, favor the transit of machines and benefit ruminants' thermal comfort. According to several experiences in Brazil (Table 10.4), the most effective arrangement is the alleys, where trees are planted in strips (single or multiple rows) with wide spacing between strips. This basic arrangement can also be adjusted according to the commercial use of wood (Porfirio-da-Silva et al. 2009). For the tree component, there basically are two primary considerations in a silvopastoral system: (i) production of a great volume of fine wood (firewood, charcoal, stanchions, podiums, etc.) in the initial part of the trees rotation (i.e. about 6 years for Eucalyptus sp.). In this case, establishment should use the highest number of trees per area possible without limiting understory growth, usually between 600 and 1000 trees per hectare; and (ii) production of thick wood (for sawmill, rolling, etc.) in the final part of trees rotation (over 10 years old, depending on species and site) by planting few trees per area, i.e. about 250 trees per hectare. The different arrangements may be planted more closely spaced and managed by thinning trees over the development period to produce wood for different purposes (thin wood in the early years of the silvopastoral system and timber in the final years of the rotation).

In cold zones of Brazil, silvopastoral systems are commercially oriented and the predominant tree species used are grown to produce wood products (Table 10.3). The productivity and the quality of tree products in silvopastoral systems depends on the genetics involved (trees, forage crops, and livestock), the quality of the site (climate and soil), the spatial arrangement of trees, and management practices applied on arboreal, forage and animal components. Few studies have analyzed the productivity and quality of tree components in silvopastoral systems compared to conventional plantations in southern Brazil. For example, a 4 year silvopastoral system initiated with the goal of producing wood logs at 424 trees ha $^{-1}$ showed mean annual increment of $33.2 \mathrm{~m}^{3} \mathrm{ha}^{-1}$ year $^{-1}$, whereas for the clone E. urophylla $\times E$. grandis on a monoculture at 1111 trees ha ${ }^{-1}$ was $43.5 \mathrm{~m}^{3} \mathrm{ha}^{-1}$ year $^{-1}$. In terms of biomass produced in the system at 1111 trees ha $^{-1}$ was the most productive. However, the volume per tree at 424 trees $\mathrm{ha}^{-1}$ was the greatest at $0.313 \mathrm{~m}^{3}$ per tree, whereas at 1111 trees ha $^{-1}$ volume reached only $0.156 \mathrm{~m}^{3}$ per tree (Medeiros, unpublished data).

\subsection{Animal Performance and Behaviour under Trees}

The use of grazing animals in commercial forests must be planned taking into account that these activities require distinct management strategies. These integrated systems aim to improve production per unit area, whereas respecting the principle of sustained yield, maintaining the productive potential of renewable natural resources, and social and economic conditions of the local community (Silva and Saibro 1998). However, within a systemic view, the animal component demands attention because the positive interaction between

Table 10.4 Regular tree spacing and arrangement applied in silvopastoral systems in southern Brazil

\begin{tabular}{l|l|l|l|l|l|l}
\hline & \multicolumn{3}{l}{ Thin wood (charcoal, firewood, fence posts) } & \multicolumn{2}{l}{ Logs (timber) } \\
\hline Tree arrangement & $\begin{array}{l}\text { Tree spacing } \\
(\mathrm{m})\end{array}$ & $\begin{array}{l}\text { Trees per } \\
\mathrm{ha}^{\mathrm{a}}\end{array}$ & $\begin{array}{l}\text { \% Area occupied } \\
\text { per row }\end{array}$ & $\begin{array}{l}\text { Tree spacing } \\
(\mathrm{m})\end{array}$ & $\begin{array}{l}\text { Trees per } \\
\text { ha }^{\mathrm{a}}\end{array}$ & $\begin{array}{l}\text { \% Area occupied } \\
\text { per row }\end{array}$ \\
\hline Single row & $14 \times 2$ & 357 & 14 & $14 \times 4$ & 179 & 14 \\
\hline Single row & $14 \times 2$ & 357 & 14 & $28 \times 4$ & 89 & 7 \\
\hline Double row & $14 \times 2 \times 3$ & 417 & 25 & $18 \times 3$ & 185 & 11 \\
\hline Triple row & $14 \times 3 \times 1.5$ & 1000 & 40 & $20 \times 3$ & 167 & 10 \\
\hline
\end{tabular}

Tree mortality was not included over the time (Adapted from Porfírio-da-Silva et al. 2009) 
tree-animal-pasture in a silvopastoral system is driven by correct decisions with regard to stocking rate or grazing intensity and this is related to carrying capacity of understory pastures, as well as grazing behavior.

\subsubsection{Animal Behavior and Performance under Eucalypt-Pasture Systems}

The first study of animal performance in a silvopastoral system with eucalyptus in Rio Grande do Sul State was conducted in an area of 180 ha and tree spatial arrangement of $2 \times 3 \mathrm{~m}$. From June 1992 to March 1993 a test with 87 zebu heifers, up to 2 years old and average liveweight of $221 \mathrm{~kg}$ was conducted during which the animals were rotationally grazed. The animals gained $0.567 \mathrm{~kg}$ per day with a gain per area of $12.55 \mathrm{~kg} \mathrm{ha}^{-1}$ (Silva et al. 1993). The total global radiation at the ground level inside the system ranged from $18 \%$ in summer to $22 \%$ in winter, compared to full sunlight (Ferreira et al. 1993). The forest allowed better environment for animal welfare, because, as compared to open pasture, temperature was warmer in winter and cooler in summer (Krause et al. 1993).

In another study, the impact of cattle and sheep grazing during the establishment phase of an Eucalyptus saligna forest with different tree densities was evaluated (204, 400 and 816 trees $\mathrm{ha}^{-1}$ ) in the Central area of Rio Grande do Sul (Varella 1997; Varella and Saibro 1999). The authors concluded that the damage caused by cattle and sheep to trees was severe when tree height was less than $182 \mathrm{~cm}$ for weaned calves and $154 \mathrm{~cm}$ for lambs. Therefore, grazing could start at 6-7 months of eucalypt age in this region. This study also showed that cattle frequently caused damage by chewing leaves and tips of lateral or apical branches, trampling seedlings, and by rubbing or scratching seedlings. The previous experience of the animals to graze under these systems and the availability and quality of understory pasture also affected the extent of damage to seedlings. The authors concluded that animals could work as efficient biological tools to control herbaceous competition to seedlings at the establishment phase and this would be more economical than the use of pre and post emergent herbicides, in addition to reducing the risks of fire inside the forest. In a subsequent study, the impact of grazing on the growth of Eucalyptus saligna over the establishment phase was evaluated. Fucks (1999) showed that sheep grazing grassland under trees with an offer of $10 \%$ (i.e. $10 \mathrm{~kg}$ of DM per $100 \mathrm{~kg} \mathrm{LW}$ per day) resulted in significant increase in tree height and diameter at breast height $(\mathrm{DBH})$ and this produced a greater volumetric increment rate and better quality of forest product at the three eucalypt densities. These results showed a benefit of animal presence and positive effects on tree development due to a decrease of understory herbaceous competition.

In the central area of Rio Grande do Sul, Silva et al. (1998) studied the effects of three grazing intensities (forage allowance of $6 \%, 9 \%$ and $13 \%$ i.e. 6,9 and $13 \mathrm{~kg}$ of pasture dry matter per $100 \mathrm{~kg}$ LW per day) and two eucalypt densities (1666 and 833 trees ha ${ }^{-1}$ ) on animal behavior and performance (Fig. 10.4). This experimental site consisted of Eucalyptus saligna and annual ryegrass (Lolium multiflorum L.) + arrowleaf clover (Trifolium vesiculosum Savi cv. Yuchi) overseeded on native pasture. Continuous grazing with steers started when trees were at an average of $2.30 \mathrm{~m}$ height (9 months old) and stocking rates were adjusted monthly according to forage supply. The author reported that survival and growth of trees (tree height and diameter) were not affected by stocking at all grazing intensities and tree densities. Only $4.4 \%$ of trees were damaged by steers, but without affecting further tree growth. It was shown that grazing management in silvopastoral systems, without limiting forage intake and quality of available forage, resulted in good animal performance and tree development. In addition, the mean daily gain (MDG) of steers was represented by a linear model, whereas the mean gain per area (MGA) was a curvilinear relation under 1666 trees ha-1 (Fig. 10.4a). Under the 833 trees $\mathrm{ha}^{-1}$, both MDG and MGA were fitted by curvilinear models (Fig. 10.4b). Silva 
Fig. 10.4 Relationship between mean daily gain $(M D G)$ and mean gain per area $(M G A)$ with pasture allowance (kg DM per $100 \mathrm{~kg}$ liveweight) under 1666 (5a) and 833 (5b) eucalypt trees per hectare and respective stocking rates $(5 \mathrm{c})$ in a silvopastoral system with eucalypt, annual ryegrass and arrowleaf clover (Trifolium vesiculosum). Data are average of three replicates collected from 6th September and 9th November 1995 at UFRGS
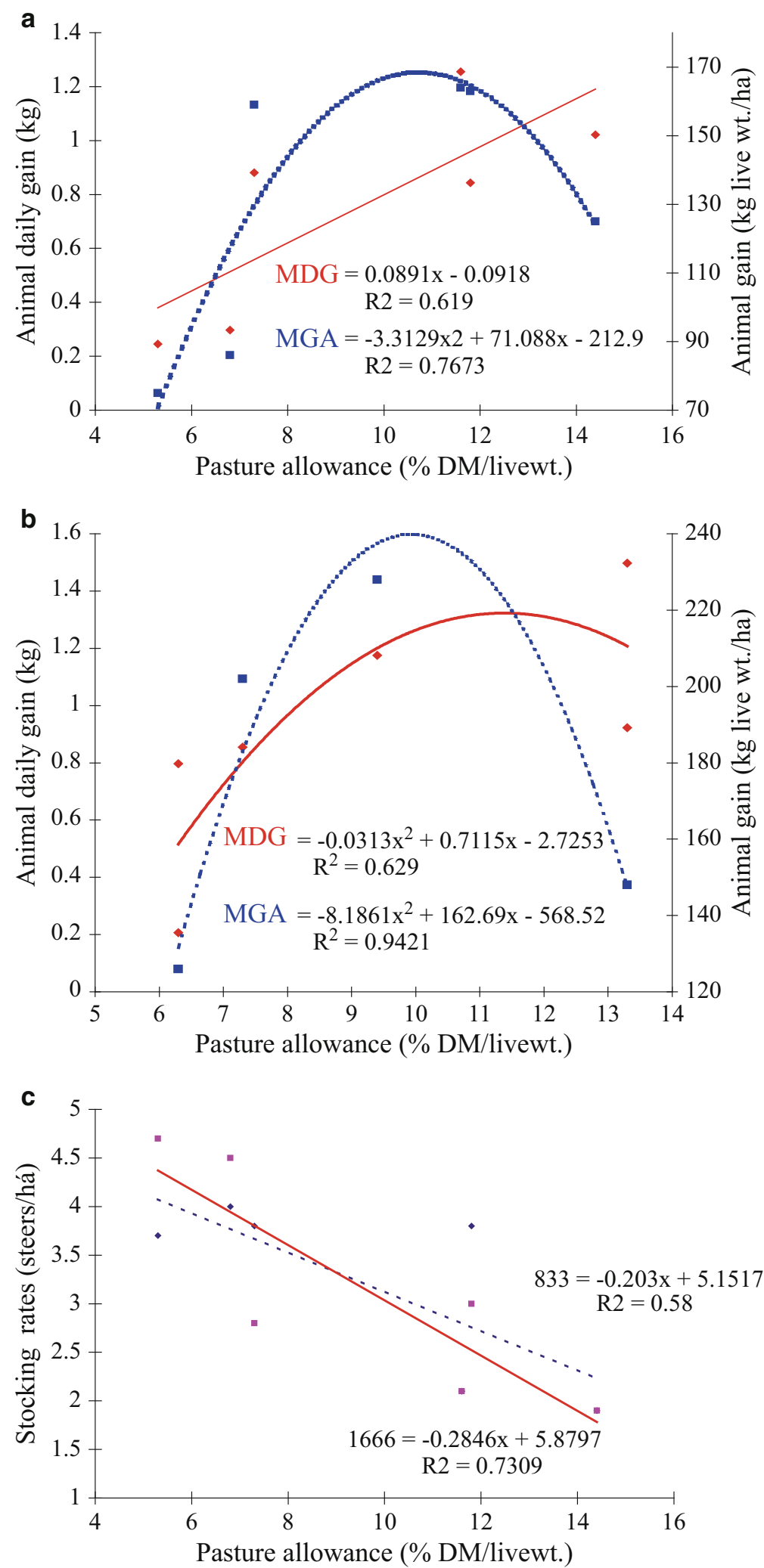
(1998) concluded that gain per animal in a silvopastoral system increased with forage supply. The gain per area decreased at the lowest pasture allowance because of reduced individual performance by animals. Above $11 \%$ of pasture allowance, MGA was also reduced due to low stocking rates (Fig. 10.4c). At intermediate stocking rate the optimum animal LWG per head and per area were obtained. For instance, the animal performance was about $220 \mathrm{~kg} \mathrm{LWG}$ per ha at 10 $\%$ of herbage allowance during the first grazing period (i.e. 64 grazing days) under 833 trees ha ${ }^{-1}$. In contrast, under 1666 trees ha $^{-1}$, animal performance was $161 \mathrm{~kg} \mathrm{LWG}$ per ha at the same grazing intensity level. The best animal performance obtained in 2 years of experiment time was $455 \mathrm{~kg}$ LWG per ha under 833 trees ha ${ }^{-1}$ with stocking rates adjusted to $10 \%$ of pasture allowance. This performance was $108 \%$ higher than under 1666 trees $\mathrm{ha}^{-1}$, showing the importance of low densities to get best results in silvopastoral systems. As a reference, average animal production on open native pastures is about $70 \mathrm{~kg} \mathrm{LWG}$ per ha per year at the same location in southern Brazil (Maraschin 1998). Under the lowest tree population, animal production was $30 \%$ greater than the highest tree population in the first year after tree establishment and this result doubled by the second year of the experiment. In addition, grazing was interrupted under 1666 trees $\mathrm{ha}^{-1}$ at tree age of 1.5 years, mainly due to strong shading to understory pasture (Silva et al. 1996). The conclusion of this study was that optimum pasture allowance in a silvopastoral system ranged from 9 to $11.5 \%$ (Silva et al. 2011), whereas in open grasslands of southern Brazil, ranges between 9.5 and $12 \%$ have been reported (Moraes et al. 1995; Maraschin 1998).

\subsubsection{Animal Behavior and Performance under Black Wattle-Pasture Systems}

The first study involving cattle grazing under black wattle was conducted in a commercial forest at 2 years old during winter period in Rio Grande do Sul State in 1992. The conclusions of this work were: (i) beef cattle were well adapted under the Acacia forest and were harmless to trees when stocking rates were controlled at intermediate levels; (ii) the integration of forestry and cattle grazing was profitable, showing a mean gross margin of $6.28 \%$; (iii) the costs of maintaining the forest and livestock are minimized by sharing infrastructure and human resources.

In 1995, a long-term experiment was established by the Rio Grande do Sul State Foundation for Agricultural Research (FEPAGRO) in collaboration with UFRGS and a private forestry company. This study was located in Tupanciretã (RS) with the aim to evaluate the interactions at soil-plant-animal-microclimate interface in a silvopastoral system with two populations of Acacia mearnsii and three understory $\mathrm{C}_{4}$ pastures: Brachiaria brizantha, Panicum maximum cv. Gatton, and grassland infested by Annoni grass (Eragrostis plana), an undesirable weedy species. Beef cattle grazed pastures continuously with stocking adjustments to maintain pasture allowance between 10 and $12 \%$. The results showed $66 \mathrm{~kg}$ LWG per ha grazing on $P$. maximum and $33 \mathrm{~kg}$ LWG grazing on $B$. brizantha pastures during 63 days in winter under a $2 \times 3 \mathrm{~m}$ Acacia mearnsii forest. In contrast, mean gain per ha increased to 75 and $60 \mathrm{~kg}$ grazing $P$. maximum and $B$. brizantha, respectively, under a

Table 10.5 Average daily gain (LWG) per animal and per hectare and stocking rate in silvopastoral systems with black wattle and perennial $\mathrm{C}_{4}$ pastures grazed for 63 days in the winter

\begin{tabular}{l|l|l|l|l|l|l}
\hline \multirow{2}{*}{$\begin{array}{l}\text { Understory } \\
\text { pasture }\end{array}$} & \multicolumn{5}{l}{ Tree density } \\
\cline { 2 - 7 } & 1667 trees ha ${ }^{-1}(2 \times 3 \mathrm{~m})$ & Kg trees ha $^{-1}(2 \times 5 \mathrm{~m})$ \\
\hline & Kg LWG (per day) & Kg LWG (per ha) & Heads/ha & Kg LWG (per day) & Kg LWG (per ha) & Heads/ha \\
\hline P. maximum & 0.536 & 66 & 2.2 & 0.627 & 75 & 2.6 \\
\hline B. brizantha & 0.750 & 33 & 1.6 & 0.726 & 60 & 2.8 \\
\hline
\end{tabular}

Data are averages of two replicates. FEPAGRO experimental site in Tupanciretã/RS (Castilhos et al. 1999) 
$2 \times 5 \mathrm{~m}$ Acacia forest (Table 10.5). These systems proved to be efficient during the winter season when beef cattle usually lose LW in open grasslands of southern Brazil. Over summer, animal performance under trees increased to 169 and $195 \mathrm{~kg}$ LWG per ha under the $2 \times 5 \mathrm{~m}$ Acacia forest grazing $P$. maximum and $B$. brizantha, respectively (Table 10.6). The authors concluded that the silvopastoral systems with black wattle were sustainable, showing potential increase in animal production and income, particularly at low tree densities, for beef farms in Rio Grande do Sul.

At year 6 in this study, both tree densities were thinned to $50 \%$ of the original population and $B$. brizantha and $E$. plana pastures were replaced by Panicum maximum cv. Aruana and Digitaria diversinervis, respectively, in the experimental plots. At this stage, Castilhos et al. (2009) reported that black wattle showed similar volume production $\left(\mathrm{m}^{3} \mathrm{ha}^{-1}\right)$ with or without grazing at 7 years after planting. For instance, Castilhos et al. (2009) showed that the volume of wood produced at this experimental site was 166, 143, 86 and $51 \mathrm{~m}^{3} \mathrm{ha}^{-1}$ under the Acacia populations of 1667 , 1000,833 and 500 trees ha $^{-1}$, respectively. In addition, animal performance on $D$. diversinervis showed the greatest daily liveweight gain of all pastures as a result of higher nutritive value compared to $P$. maximum. However, this $\mathrm{C}_{4}$ pasture provided the lowest grazing-days as a result of a remarkable decrease in pasture yield during the water stress period occurred in summer. According to the authors, this result explained the lowest liveweight gain per area and carrying capacity of $D$. diversinervis of all pastures under trees. In contrast, both $P$. maximum cultivars showed greater carrying capacities and gains per hectare compared to $D$. diversinervis (Table 10.7). The conclusion of this study was that silvopastoral systems using populations of Acacia mearnsii lower than 833 trees ha ${ }^{-1}$ compromised wood production, whereas increased animal performance grazing underneath $\mathrm{C}_{4}$ pastures. From this work, it was also shown that Annoni Grass (E. plana) was shade intolerant. Several authors report Annoni Grass as the main weed that degrades southern Brazil rangelands and occupy about $20 \%$ of the total area. Therefore, the tree- pasture systems become a sustainable alternative to recover those infested areas by using shade tolerant pastures combined to trees.

Finally, there is still a lack of scientific information on grazing behavior and animal welfare measured under silvopastoral systems. In the cold subtropical area of Brazil, livestock face extreme temperatures in winter and summer. Tree protection combined with accumulated forage may be strategic for sheep, dairy and beef farms which usually lose production at these stages. In the near future, this information may be available because a recent long term experimental site has been initiated at EMBRAPA South Livestock aiming to recover degraded grasslands by Annoni Grass and to evaluate thermal comfort of Brangus (Angus $\times$ Nelore cattle breed) at critical climate periods under silvopastoral systems.

\subsubsection{Animal Behavior and Performance under Mixed Tree Crop-Livestock System}

In southern Brazil, integration of trees, crops, and livestock in rotational systems are still unusual. Experiences have been applied by forestry companies and farmers more recently. This usually involves rotational systems between annual crops (maize, soybean, Sorghum spp., winter cereals), annual fruits (watermelon, melon, pumpkin) and pastures under spaced eucalypt plantations (Balbino et al. 2011; De Melo 2012). Likewise, experiments on mixed tree-crop-livestock systems have become frequent in scientific institutions of southern Brazil. For instance, an experiment with crop-livestock-forestry integration, using a mixture of tree species and winter pastures has been conducted since 2006 in Parana State. The tree components were Eucalyptus dunnii, Schinus terebinthifolius and Grevillea robusta and this was implemented in the Model Farm Station of IAPAR (Porfírio-da-Silva 2012). The trees were planted in an alternate arrangement within the row. The spatial arrangement was simple rows, with spacing of $14 \mathrm{~m} \times 3 \mathrm{~m}$, allocated across the predominant direction of the slope due to soil conservation issues. Since tree establish- 
Table 10.6 Pasture residual dry matter (RDM), average daily gain (ADG), average gain per area (AGA), pasture carrying capacity (CC) and stocking rate (STOCK) in silvopastoral systems with two densities of black wattle and three $\mathrm{C}_{4}$ pastures

\begin{tabular}{|c|c|c|c|c|c|c|c|c|c|c|}
\hline \multirow{3}{*}{$\begin{array}{l}\text { Understory } \\
\text { pasture }\end{array}$} & \multicolumn{10}{|l|}{ Tree density } \\
\hline & \multicolumn{5}{|c|}{1666 trees/ha $(2 \times 3 \mathrm{~m})$} & \multicolumn{5}{|c|}{1000 trees $/ \mathrm{ha}(2 \times 5 \mathrm{~m})$} \\
\hline & RDM (kg/ha) & $\begin{array}{l}\text { ADG (kg/hd/ } \\
\text { day) }\end{array}$ & $\begin{array}{l}\text { AGA }(\mathrm{kg} / \\
\text { ha) }\end{array}$ & CC (kg/ha/day) & $\begin{array}{l}\text { STOCK } \\
\text { (hd/ha) }\end{array}$ & $\begin{array}{l}\text { RDM (kg/ } \\
\text { ha) }\end{array}$ & $\begin{array}{l}\text { ADG (kg/hd/ } \\
\text { day) }\end{array}$ & $\begin{array}{l}\text { AGA (kg/ } \\
\text { ha) }\end{array}$ & $\begin{array}{l}\mathrm{CC}(\mathrm{kg} / \mathrm{ha} / \\
\text { day) }\end{array}$ & STOCK (hd/ha) \\
\hline $\begin{array}{l}\text { P. maximum } \mathrm{cv} \text {. } \\
\text { Gatton }\end{array}$ & $2422 \mathrm{~A}^{\mathrm{b}}$ & $0.644 \mathrm{~A}$ & 104 & 372 & 1.70 & $3200 \mathrm{~A}$ & $0.696 \mathrm{~A}$ & 169 & 520 & 2.55 \\
\hline $\begin{array}{l}\text { B. brizantha cv. } \\
\text { Marandu }\end{array}$ & 1720B & $0.573 \mathrm{AB}$ & 105 & 394 & 1.85 & 2995A & $0.690 \mathrm{~A}$ & 195 & 698 & 1.85 \\
\hline E. plana & 1182B & $0.539 \mathrm{AB}$ & 95 & 418 & 1.80 & 1417B & $0.417 \mathrm{~B}$ & 122 & 741 & 3.25 \\
\hline Mean $^{\mathrm{a}}$ & $1775 a$ & $0.585 \mathrm{a}$ & 101a & $395 a$ & $1.78 \mathrm{a}$ & $2537 \mathrm{~b}$ & $0.601 \mathrm{a}$ & $162 b$ & $653 b$ & $2.55 \mathrm{~b}$ \\
\hline
\end{tabular}

Pasture allowance was maintained between 10 and $12 \%$ during the period of 13th November 1998 to 18th February 1999. Data are averages of two replications. FEPAGRO experimental site in Tupanciretã/RS (Silva et al. 1999)

${ }^{a}$ Means followed by the same letter in the row, between the tree densities, do not differ at $5 \%$ probability level by Duncan test

${ }^{b}$ Means followed by the same capital letter in the column, for pastures and tree densities interactions, do not differ at $5 \%$ probability level by Duncan test 
Table 10.7 Average daily gain (ADG), Average gain per area (AGA), average daily gain per area (ADGA), grazingdays per hectare (GD) and real pasture allowance (PA) in silvopastoral systems with two populations of Acacia mearnsii and three $\mathrm{C}_{4}$ pastures

\begin{tabular}{l|l|l|l|l|l}
\hline Pasture & $\mathrm{ADG}^{\mathrm{a}}$ & $\mathrm{AGA}^{\mathrm{a}}$ & $\mathrm{ADGA}^{\mathrm{a}}$ & $\mathrm{GD}^{\mathrm{a}}$ & $\mathrm{PA}$ \\
\hline & $\mathrm{kg} / \mathrm{hd}$ & $\mathrm{kg} / \mathrm{ha}$ & $\mathrm{kg} / \mathrm{ha} / \mathrm{day}$ & An.day/ha & $\mathrm{kg} \mathrm{DM} / 100 \mathrm{~kg} \mathrm{LW}$ \\
\hline P. maximum cv. Gatton & $0.738 \mathrm{a}$ & $337.6 \mathrm{a}$ & $3.13 \mathrm{a}$ & $445.5 \mathrm{a}$ & $13.9 \mathrm{a}$ \\
\hline P. maximum cv. Aruana & $0.799 \mathrm{a}$ & $328.2 \mathrm{a}$ & $3.04 \mathrm{a}$ & $406.3 \mathrm{a}$ & $11.9 \mathrm{a}$ \\
\hline D. diversinervis & $0.844 \mathrm{a}$ & $289.7 \mathrm{a}$ & $3.11 \mathrm{a}$ & $333.9 \mathrm{a}$ & $9.4 \mathrm{a}$ \\
\hline Mean & 0.794 & 318.5 & 3.09 & 395.2 & 11.7
\end{tabular}

Pasture allowance was maintained at $12 \%$ between 1st December 2003 and 18th March 2004. Data are averages of the two tree densities and replications. FEPAGRO experimental site at Tupanciretã/RS (Lucas 2004)

${ }^{a}$ Means followed by the same letter in the column do not differ significantly by the $\mathrm{F}$ test at $5 \%$ probability

ment, the underneath area has been managed with corn and soybeans for grain production in summer and under a no till system. In winter, a mixture of black oats and annual ryegrass pastures (Avena strigosa and Lolium multiflorum) has been sown in sequence to summer crops. This experiment evaluated two levels nitrogen fertilization $\left(90 \mathrm{~kg} \mathrm{ha}^{-1}\right.$ and $\left.180 \mathrm{~kg} \mathrm{ha}^{-1} \mathrm{~N}\right)$ on understory pasture. In this agroforestry system, grazing started at 41 months of trees age. At this stage the author reported that all tree species received damage by cattle, but severity was great only on S. terebinthifolius, therefore this tree species was considered unsuitable for integration systems (Porfirio-da-Silva et al. 2012). When trees were 29 months old, corn yield was similar under the three systems, with a mean grain production of $4.1 \pm 0.3$ ton $\mathrm{ha}^{-1}$ and mean increment of wood production was $1.03 \mathrm{~m}^{3}$ per hectare over the corn cycle. In addition, the productivity of a soybean crop under trees at 56 months of age was 3.7 ton grain $\mathrm{ha}^{-1}$ or $19 \%$ less than in crop-livestock integration conducted in an adjacent area, whereas the increase in wood production was $6.6 \mathrm{~m}^{3} \mathrm{ha}^{-1}$ over this crop cycle. The mean pasture DM yield was $2210.3 \mathrm{~kg} \mathrm{ha}^{-1}$ and the mean daily gain of steers was $0.86 \pm 0.31 \mathrm{~kg} \mathrm{ha}^{-1}$ day $^{-1}$ or $440.6 \pm 75.9 \mathrm{~kg} \mathrm{ha}^{-1}$ over the two grazing cycles (Porfirio-da-Silva 2012). The author observed that fertilization of winter pastures combined with the maintenance of a residual pasture height of $20 \mathrm{~cm}$ was essential for cattle production and strategic for no till management of summer crops.

\subsection{Challenges for Research, Development and Technology Transfer on Silvopastoral Systems}

Silvopastoral systems are dynamic and complex, particularly when considering the multiple interactions between trees, pasture and livestock in time and space (Balbino et al. 2011). The experience of implementation of integrated croplivestock-forest systems in the last 25 years indicates the need for new and adapted models of production, technical assistance and rural extension for assuring the sustainability of Brazilian agriculture. To achieve that, it is important that research institutions conduct long-term experiments to investigate and transfer technologies to farmers and technicians continuously. Therefore, it is imperative that institutions develop joint programs for Research and Development (R\&D) and Technology Transfer in silvopastoral systems since trees establishment period to the harvest of forest products. In addition, it is also important to understand that public and private technical advice require more training and qualification to manage these dynamic and sustainable systems.

In southern Brazil, the potential areas for silvopastoral systems are usually the ones currently occupied with extensive beef cattle and sheep extensive systems. To increase interest in this type of integration, it is essential that R\&D offer suitable models that match producer interests and needs of the region. In this respect, issues related to animal welfare, the strategic forage supply 
during periods of extreme weather, and soil conservation should be highlighted in $R \& D$ programs. Besides, the self-consumption of wood in rural properties for energy and constructions, as well as for direct sale may also attract livestock producers to adopt these integrated systems. Therefore, the following opportunities and challenges for research and technology transfer in silvopastoral systems in southern Brazil are:

- To study new designs and spacing between trees for silvopastoral systems to allow minimum radiation level of $50 \%$ on understory plants throughout the tree cycle;

- To offer alternatives of perennial and annual forage species and mixtures tolerant to shade, as well as climate and soil conditions in southern Brazil;

- To develop new forage cultivars adapted to shade;

- To quantify the benefits of shading for animal welfare (thermal comfort, performance and grazing behavior);

- To find profitable alternatives for selling or processing of timber and other forestry products from low tree density systems;

- To develop genetic improvement of trees for integration systems, highlighting plant architecture, biological cycle and quality of harvesting product;

- To develop silvopastoral system models involving native trees and forage species to meet requirements of the Brazilian environmental laws (legal reserves) on farms;

- To improve management of farms using silvopastoral systems;

- To develop and implement new training programs for technical and extension staff for silvopastoral systems on farms;

- To quantify environmental benefits provided by silvopastoral systems (carbon balance, mitigation of greenhouse gases, soil and water conservation);

- To develop soil nutrient tables to support annual fertilization decisions for tree-pasture systems;

Besides long term experimental areas and continuous research support from agencies, it is important that institutions invest in multidisciplinary teams, capable of responding to the opportunities and challenges mentioned. Important research institutions in southern Brazil, such as units of EMBRAPA, Federal Universities, and State Research Organizations should cooperate to achieve these goals as quick as possible. A collaborative network of scientists, extension agents, and consultants should develop demonstrative areas on farms for continuous training and technology transfer developed by research institutions. Currently, in southern Brazil, there is a reasonable physical structure available for national and international research institutions able to carry on long term and collaborative works on silvopastoral systems located at different sites on this region, such as:

- The silvopastoral system experimental site located at EMBRAPA South Livestock Systems (CPPSUL): established in 2013 and located in Bagé, Rio Grande do Sul State, border area with Uruguay. It's an area of 34 ha, containing three levels of radiation on the native pasture (full sun; 800 and 400 trees $\mathrm{ha}^{-1}$ ), subdivided into two management systems (an intensive system using improved pasture with cool season forage species (annual ryegrass, red clover and birdsfoot trefoil) and a high fertility soil opposed to a conservative system using selective application of herbicide and livestock rate control) with the aim to recover degraded native pasture infested by the Annoni Grass weed (Eragrostis plana). The Eucalyptus grandis trees were established in triple rows spaced $2 \mathrm{~m}$ between plants and $3 \mathrm{~m}$ between rows. The spacing between the triple rows is $34 \mathrm{~m}$ or $14 \mathrm{~m}$, resulting in a model of $3 \times 2 \times 34 \mathrm{~m}$ and $14 \times 3 \times 2 \mathrm{~m}$.

- The experimental Farm Canguiri of the Federal University of Paraná (UFPR): located in Pinhais City, State of Parana. This area uses different integration models in order to obtain results over the complete cycle of the system: (i) integrated crop-livestock-trees system; (ii) crop-livestock system; (iii) Livestock-trees system; (iv) Crop-tree system and (v) integrated tree-pasture system. The trees were planted in single rows with Eucalyptus 
benthamii spaced $14 \mathrm{~m}$ between rows and $2 \mathrm{~m}$ within the rows at an initial density of about 250 trees $\mathrm{ha}^{-1}$. For comparative purposes, there is still a monoculture system (plantation) established with at $3 \times 2.5 \mathrm{~m}$, resulting in an initial density of 1333 trees $\mathrm{ha}^{-1}$ and a final density of 800 ha $^{-1}$.

- The Model Farm of the Agronomic Institute of Paraná (IAPAR): located in Ponta Grossa City in the South Central Region of the Paraná State. This experimental site has three major areas of study:(i) an experimental area for crop-livestock-tree system. It was established in 2006 with E. dunnii, Schinus terebinthifolius and Grevillea robusta trees, planted in single rows and spaced at $14 \times 3 \mathrm{~m}$, resulting in 238 trees ha-1. In 2013 the S. terebinthifolius was removed from experimental area because leaves and branches were noticed to be palatable to grazing animals, therefore barking and chewing became limiting for the integration (Porfírio-da-Silva et al. 2012). The total area of the experiment comprises 10.9 ha and was splitted into six paddocks of croplivestock integration and other six of treecrop-livestock system. Over the cool season, the pasture areas between trees rows were sown with a mixture of forage oats and annual ryegrass for grazing, followed by soybeans and maize in summer; (ii) to make experiments in plots with understory plants and between the double rows of Eucalyptus dunni. It was established in 2007 in the density of 330 trees ha ${ }^{-1}(21 \times 4 \times 3 \mathrm{~m})$. After thinning in 2011, the density decreased to 155 trees $\mathrm{ha}^{-1}$ (Pontes et al. 2012).; (iii) to make experiments with different densities and spatial arrangements of trees, Eucalyptus benthamii was established in 2008 in single, double and triple rows of trees. The spacing between rows is 21 $\mathrm{m}$, resulting in the following spatial arrangements: $21 \times 2$ (single line); $21 \times 2 \times 3$ (double line) and $21 \times 2 \times 3$ (triple line).

Acknowledgements The authors acknowledge the research groups from UFPR, UFRGS, UTFPR Pato Branco, FEPAGRO and IAPAR) for have kindly offered information about the Experimental sites and progressing studies.

We also acknowledge Professor Emeritus Don Ball from Auburn University for English and for technical review of this chapter and valuable comments on the text.

\section{References}

Alfenas AC, Jeng RS, Hubbes M (1983) Virulence of Cryphonectria cubensis on Eucalyptus species differing in resistance. Eur J Plant Pathol 13(4):197-205

Amaral MF, Mezzalira JC, Bremm C et al (2013) Sward structure management for maximum short-term intake rate in annual ryegrass. Grass For Sci 68:271-277

Associação Brasileira de Produtores de Florestas Plantadas (ABRAF) Anuario Estatistico da ABRAF 2010 ano base 2009. Brasilia/DF, 2010. 140p. Available in: http://www.ipef.br/estatisticas/relatorios/ anuario-ABRAF-2010-BR.pdf. Accessed 3 Nov 2015

Baggio AJ, Schreiner HG (1988) Análise de um sistema silvipastoril com Pinus elliottii e gado de corte. In: Boletim de Pesquisa Florestal (16). Available from EMBRAPA. http://ainfo.cnptia.embrapa.br/digital/ bitstream/CNPF-2009-09/4854/1/baggio.pdf. Accessed July 2015

Balbino LC, Cordeiro LAM, Porfirio-Da-Silva V et al (2011) Evolução tecnológica e arranjos produtivos de sistemas de integração lavoura-pecuária-floresta no Brasil. Pesq Agrop Brasileira 46(10):1-12

Baldissera TC (2014) O ambiente luminoso: do impacto no crescimento e desenvolvimento em nível de planta forrageira a dosséis em sistemas integrados de produção agropecuária. Thesis, Universidade Federal do Paraná

Baldissera TC, Pontes LS, Barro RS et al (2014) Altura do dossel forrageiro de seis espécies perenes tropicais em sistema arborizado. In: 1st Simpósio Internacional de Arborização de Pastagens em Regioes Subtropicais, Colombo: Embrapa Florestas

Balocchi OA, Phillips CJC (1997) Grazing and fertilizer management for establishment of Lotus uliginosus and Trifolium subterraneum under Pinus radiata in southern Chile. Agrofor Syst 37:1-14

Barro RS, Saibro JC, Silva JLS et al (2006) Rendimento de matéria seca de cinco forrageiras de ciclo hibernal sob duas densidades arbóreas de Pinus elliotti e ao sol pleno. In: Proceedings of 43rd Reunião Anual da Sociedade Brasileira de Zootecnia, João Pessoa

Barro RS, Saibro JC et al (2008) Rendimento de forragem e valor nutritivo de gramíneas anuais de estação fria submetidas a sombreamento por Pinus elliottii e ao sol pleno (Forage yield and nutritive value of cool-season annual forage grasses shaded by Pinus elliottii trees and at full-sun). R Bras de Zootec 37:1721-1727

Barro RS, Varella AC, Bangel FV et al (2010) Screening native $\mathrm{C} 4$ pasture genotypes for shade tolerance in Southern Brazil. In: Proceedings of 15th Australian 
Society of Agronomy Conference, Lincoln, November 2010

Barro RS, Varella AC, Lemaire G et al (2012) Forage yield and nitrogen nutrition dynamics of warm-season native forage genotypes under two shading levels and at full sun. Braz J Ann Sci 41:1589-1597

Barro RS, Saibro JC, et al (2014) Morphological acclimation and canopy structure characteristics of Arachis pintoi under reduced light and in full sun. Trop Grassl 2:15-17

Castilhos ZMS, Silva JLS, Guterres E et al (1999) Desempenho de espécies forrageiras de verão em sistema silvipastoril com acácia negra (Acacia mearnsii de Wild). In: Proceedings of 36th Reunião anual da Sociedade Brasileira de Zootecnia, Porto Alegre

Castilhos ZMS, Barro RS, Savian JF et al (2009) Produção arbórea e animal em sistemas silvipastoril com acácianegra (Acacia mearnsii). Braz J Med Biol Res 60:39-47

Ceballos, JC, Bottino, MJ (2006) Solar radiation in South America, period 1998-2004: Some aspects of a satellite-based data base. In: XIV Congresso Brasileiro de Meteorologia, 2006, Florianópolis, SC. Anais do XIV Congresso Brasileiro de Meteorologia. Available in:http://www.cbmet.com/ cbm-files/14-06214951bf3c0dff83741779 33b83865.pdf. Accessed 3 Nov 2015

Chang MY (1985) Faxinais no Paraná. Instituto Agronômico do Paraná - IAPAR, Londrina

Da Silva SC, Bueno AAO, Carnevalli RA et al (2009) Sward structural characteristics and herbage accumulation of Panicum maximum cv. Mombaça subjected to rotational stocking managements. Sci Agric 66(1):8-19

Da Trindade JK, Da Silva SC, Souza SJ Jr et al (2007) Composição morfológica da forragem consumida por bovinos de corte durante o rebaixamento do capimmarandu submetido a estratégias de pastejo rotativo. Pesq Agrop Brasileira 42(6):883-890

Deiss L, Moraes A, et al (2014) Oat tillering and tiller traits under different nitrogen levels in an eucalyptus agroforestry system in subtropical Brazil. Cienc Rural (1):71-78

IBGE Instituto Brasileiro de Geoestatística (2006) Sistema IBGE de Recuperação Automática. Banco de Dados Agregados. Estabelecimentos na agropecuária: unidades Brasil IBGE, Rio de Janeiro. http://www.sidra.ibge.gov.br/bda/pecua/default. asp? $\mathrm{z}=\mathrm{t} \& \mathrm{o}=24 \& \mathrm{i}=\mathrm{P}$

Ferreira VP, Schaffer G, Krause CA et al (1993) Microclima de floresta de eucalipto no Rio Grande do Sul: II- distribuição da radiação solar. In: Proceedings of VIII Congresso Brasileiro de Agrometeorologia, Porto Alegre, July 1993

Ferreira ASJF, Valentim CMS, Andrade GML et al (2006) Distribuição da biomassa de raiz de genótipos de Panicum spp. nas condições ambientais do Acre. In: Anais Reunião Anual da Sociedade Brasileira de Zootecnia, 43, SBZ, João Pessoa, PB.
2006. Available in: http://www.sbz.org.br/reuniaoanual/anais/?idiom=en. Accessed 8 Jan 2016

Filho Paludzyszyn E, dos Santos PET (2013) Escolha de cultivares de eucaliptos em função do ambiente e do uso. Comunicado Técnico (316). Available from EMBRAPA. http://ainfo.cnptia.embrapa.br/digital/ bitstream/item/97498/1/CT-316-Escolha-decultivares.pdf. Accessed 05 July 2015

Fucks LFM (1999) Dinâmica da pastagem nativa, desempenho de ovinos e desenvolvimento arbóreo em sistema silvipastoril com três populações de Eucalyptus saligna. Thesis, Universidade Federal do Rio Grande do Sul

Gutmanis D (2004) Estoque de carbono e dinâmica ecofisiológica em sistemas silvipastoris. Thesis, Universidade Estadual Paulista

Higa RCV, Wrege M (2010) Zoneamento climatico de Eucalyptus grandis para a região Sul do Brasil. In: Documentos (209), Available from EMBRAPA. http:// www.infoteca.cnptia.embrapa.br/infoteca/bitstream/ doc/883452/1/Doc209.pdf. Accessed 05 July 2015

Johnson SE, Sollenberger LE et al (2002) Nutritive value of rhizoma peanut growing under varying levels of artificial shade. Agron J 94:1071-1077

Jovanovic T, Booth T (2002) Improved species climatic profiles: a report for the RIRDC/L\&W Australia/ FWPRDC/MDBC Joint Venture Agroforestry Program. In: RIRDC Publication (02/095). Available from https://rirdc.infoservices.com.au/items/02-095

Kirchner R, Soares AB, Sartor L et al (2010) Desempenho de forrageiras hibernais sob distintos níveis de luminosidade. Braz J Vet Res Anim Sci 39:2371-2379

Krause CA, Aragones RS, Ferreira VP et al (1993) Microclima de floresta de eucalipto no Rio Grande do Sul: I- temperatura, umidade relativa e velocidade do vento. In: Proceedings of VIII Congresso Brasileiro de Agrometeorologia, Porto Alegre

Lucas NM (2004) Desempenho animal em sistema silvipastoril com acácia-negra (Acacia mearnsii de wild.) e rendimento de matéria seca de cultivares de panicum maximum jacq. sob dois regimes de luz solar. Thesis, Universidade Federal do Rio Grande do Sul, Porto Alegre, RS

Maraschin GE (1998) Utilização, manejo e produtividade das pastagens nativas da região Sul do Brasil. In: Proceedings of Ciclo de Palestras em Produção e Manejo de Bovinos de Corte. Ênfase: manejo e utilização sustentável de pastagens, ULBRA, Canoas/RS

Martins EG, Neves EJM, Sturion JA et al (2015) Volume de madeira e ganho genético de progênies de grevílea (Grevíllea robusta Cunn.) de segunda geração na região de Londrina, Paraná. Boletim de Pesquisa Florestal (51). Available from EMBRAPA. http:// ainfo.cnptia.embrapa.br/digital/bitstream/ item/117556/1/boletim51-pag45-55.pdf. Accessed 05 July 2015

Melo IB (2012) Integração lavoura-pecuária-floresta no norte do Rio Grande do Sul: estudo de caso. In: Fontaneli RS, dos Santos HP, Fontaneli RS (eds) 
Forrageiras para integração lavoura-pecuária-floresta na região sul-brasileira, 2ed, Brasília, pp 461-487

Melotto A, Nicodemo MLF, Bocchese RA et al (2009) Sobrevivência e crescimento inicial em campo de espécies florestais nativas do brasil central indicadas para sistemas silvipastoris. Rev Árvore 33(3):425-432

Montoya LJV et al (1994) Aspectos de arborização de pastagens e viabilidade técnica e econômica da alternativa silvipastoril. In: Luciano J. Montoya Vilcahuaman; Moacir J. Sales Medrado. (Org.). I Seminário sobre Sistemas Agroflorestais na Região Sul. Curitiba Paraná 5:157-171

Moraes A, Maraschin GE, Nabinger C (1995) Pastagens nos ecossistemas de clima subtropical pesquisas para o desenvolvimento sustentável. In: Proceedings of Simpósio sobre Pastagens nos Ecossistemas Brasileiros: Pesquisa para o Desenvolvimento Sustentável, Brasília

Nicodemo MLF, Porfírio-Da-Silva V, Pezzopane JRM et al (2010) Desenvolvimento de árvores nativas em sistemas silvipastoril e agrossilvipastoril na região Sudeste. In: Proceedings of 47th Reunião Anual da Sociedade Brasileira de Zootecnia, Salvador

Otto GM, Motta ACV, Reissman CB (2009) Adubação nitrogenada em sistema silvipastoril álamo: pastagens de inverno. Rev Árvore 33(3):443-441

Pedreira BC, Pedreira CGS, Da Silva SC et al (2007) Estrutura do dossel e acúmulo de forragem de Brachiaria brizantha cv. Xaraés em resposta a estratégias de pastejo. Pesq Agrop Brasileira 42(2):281-287

Pontes LS, Giostri AF, Baldissera T et al (2012) Interactive tree and $\mathrm{N}$ supply effect on six $\mathrm{C} 4$ forage grasses productivity. In: II International symposium on integrated crop-livestock systems, Porto Alegre

Pontes LS, Baldissera TC, Barro RS, et al (2014) Interactive $\mathrm{N}$ supply and cutting intensity effect on canopy height at $95 \%$ light interception. In: General meeting of the European Grassland Federation

Porfirio-Da-Silva V (2012) Produtividade em sistema de integração lavoura-pecuária-floresta no subtrópico brasileiro. Thesis, Universidade Federal do Paraná

Porfirio-Da-Silva V, Medrado MJS, Nicodemo MLF et al (2009) Arborização de pastagens com espécies florestais madeireiras: implantação e manejo. Embrapa Florestas, Colombo

Porfírio-Da-Silva V, Moraes A, Moletta JL et al (2012) Danos causados por bovinos em diferentes espécies arbóreas recomendadas para sistemas silvipastoris. Pesq Florestal Brasileira 3(70):67-76

Radomski MI, Ribaski J (2010) Excentricidade da medula em Grevillea robusta e Corymbia citriodora cultivados em sistema silvipastoril. Embrapa Florestas. Comunicado técnico, 248 Colombo: Embrapa Florestas, $4 \mathrm{pp}$

Ribaski J, Dedececk RA, Mattei VL et al (2005) Sistemas silvipastoris: estratégias para o desenvolvimento rural sustentável para a metade sul do Estado do Rio Grande do Sul. Embrapa Florestas Comunicado Técnico 150
Saibro JC (1992) Programa de estímulo à integração de grupos e centros de pesquisa com o setor empresarial. Integração Silvipastoril de Eucalipto com Pastagens na Depressão Central no Rio Grande do Sul. (Proc. No 91/1684-3). Annual Technical Report, 1992. Fapergs/ Riocell S.A./Ufrgs, Porto Alegre

Saibro JC (2001) Animal production from tree-pasture association systems in Brazil. In: International Grassland Congress, Lecture FEALQ, São Pedro

Saibro JC, Barro RS (2009) Indicadores biofísicos e sustentabilidade em sistemas silvipastoris In: Workshop Integração Lavoura-Pecuária- Floresta No Bioma Pampa, Embrapa Clima Temperado (ed). Pelotas 2009 SBS. Sociedade Brasileira de Silvicultura (2008) Fatos e Números do Brasil Florestal. Dezembro, 2008. Available in: http://www.sbs.org.br/ FatoseNumerosdoBrasilFlorestal.pdf. Accessed 14 Sept 2014

Saibro JC, Medeiros R, Silva JL et al (2008) Rendimento de forragem e valor nutritivo de gramíneas anuais de estação fria submetidas a sombreamento por Pinus elliottii e ao sol pleno (Forage yield and nutritive value of cool-season annual forage grasses shaded by Pinus elliottii trees and at full-sun). Braz J Ann Sci 37:1721-1727

Sampaio OB, Schaffrath VR, Pinto ER. (2009) Sistema silvipastoril em pastagens naturais e artificiais. In: Congresso Brasileira de Sistemas Agroflorestais, 7. Proceedings 2009, Luziânia-GO, 5p. Available in: http://www.sct.embrapa.br/cdagro/tema02/02tema07. pdf. Accessed 7 Sept 2014

Sartor LR, Soares AB, Adami P et al (2006) Produção de forragem de espécies de inverno em ambiente sombreado. SynScy 1:13-21

Schreiner HG (1987) Tolerância de quatro forrageiras a diferentes graus de sombreamento. Pesq Agropec Bras 61-72

Schreiner HG (1994) Relatório de consultoria técnica em agrossilvicultura. Centro Nacional de Pesquisa de Florestas/EMBRAPA, Colombo/PR, Brazil, 76

Sentelhas PC, Angelocci LR (2012) Geada: ocorrência, prevenção e controle. Slide class of discipline Agricultural Meteorology LCE306. Available in: http://www.leb.esalq.usp.br/aulas/lce306/ Aula12_2012_Geada_modificada_em_pdf.pdf. Accessed at 16 Aug 2014

Silva JLS (1998) Produtividade de componentes de um sistema silvipastoril constituído por Eucalyptus saligna e pastagens cultivada e nativa no Rio Grande do Sul. Thesis, Univesidade Federal de Viçosa

da Silva SC, Carvalho PCF (2005) Foraging behaviour and herbage intake in the favourable tropics/subtropics. In: McGilloway DA (Org.). Grassland: a global resource. Wageningen Academic, Wageningen, pp 81-95

Silva JLS, Garcia R et al (1996) Desempenho de bovinos e seus efeitos sobre as árvores em florestas de eucalipto (Eucalyptus saligna) na região fisiográfica da Depressão Central do RS. In: Simpósio Internacional Sobre Ecossistemas Florestais, Belo Horizonte, 1996 
Silva JLS, Saibro JC (1998) Utilização e manejo de sistemas silvipastoris. In: Ciclo De Palestras Em Produção e Manejo de Bovinos de Corte. Ênfase: manejo e utilização sustentável de pastagens. Anais. Canoas. ULBRA, pp 3-28

Silva JLS, Saibro JC, Soares LHB (1993) Desempenho produtivo de bovinos via pastejo do sub-bosque forrageiro em mata de eucalipto. In: Reunião anual da Sociedade Brasileira de Zootecnia, 30. SBZ. Anais, Rio de Janeiro, pp 61

Silva JLS et al (1998) Desempenho animal e de pastagem de inverno em sistema silvipastoril com eucalipto no ano de seu estabelecimento no RS. In: Proceedings Reunião Anual da Sociedade Brasileira de Zootecnia, 1998

Silva JLS, Castilhos ZMS, Savian JF et al (1999) Desempenho animal e forragem residual em sistema silvipastoril com acácia-negra (Acacia mearnsii de Wild) e pastagens de verão no RS. In: XXXVI Reunião anual da Sociedade Brasileira de Zootecnia. SBZ. Anais. Porto Alegre, pp 015

Silva JLS, Saibro JC, Sousa ZMC (2001) Situação da pesquisa e utilização de sistemas silvipastoris no rio grande do sul. In: Sistemas Agroflorestais Pecuários: Opções De Sustentabilidade Para Áreas Tropicais e Subtropicais. Carvalho MM, Alvim MJ, Carneiro JC (Org.) Brasília, pp 258-283

Silva JLS et al (2009) Desenvolvimento de sistemas silvipastoris no Rio Grande do Sul. In: Workshop Integração Lavoura-Pecuária-Floresta $\mathrm{Na}$ Embrapa Resumos e palestras apresentados. Brasília: Embrapa, 2009

Silva JLS, Varella AC, Saibro JC, Castilhos ZMS (2011) Manejo de animais e pastagens em sistemas de integração silvipastoril. Embrapa Clima Temperado Documentos 335. Pelotas, $98 \mathrm{pp}$

Soares AB, Sartor LR, Adami PF et al (2009) Influência da luminosidade no comportamento de onze espécies forrageiras perenes de verão. Braz $\mathrm{J}$ Ann Sci 38:443-451

United Nations/FAO (2014) El estado de los Bosques del Mundo-Potenciar los beneficiossocioeconómicos de los bosques. Roma. Available in: http://www.fao. org/3/a-i3710s.pdf. Accessed at 14 Sept 2014

Varella AC (1997) Uso de herbicidas e de pastejo para o controle da vegetação nativa no ano do estabelecimento de três densidades de Eucalyptus saligna Smith. Dissertation, Universidade Federal do Rio Grande do Sul

Varella AC, Saibro JC (1999) Uso de bovinos e ovinos como agentes de controle da vegetação nativa sob três populações de eucalipto. Braz J Ann Sci 28(1):30-34

Varella AC, Ribaski J, Silva VP et al (2008) Recomendações para a escolha e manejo de plantas forrageiras em sistemas silvipastoris no Sul do Brasil. Série EMBRAPA, Documentos 76

Varella AC, Silva VP, Ribaski J et al (2009) In: Fontaneli RS, Santo HP, Fontaneli RS (Org) (eds) Estabelecimento de Plantas Forrageiras em Sistemas de Integração Floresta-Pecuária no Sul do Brasil. Forrageiras para a Integração Lavoura-PecuáriaFloresta na Região Sul-Brasileira Embrapa Trigo, Passo Fundo, pp 283-303

Varella AC, Moot DJ, Pollock KM, Peri PL, Lucas RJ (2011) Do light and alfalfa responses to cloth slatted shade represent those measured under an agroforestry system? Agrofor Syst 81:157-173

Watson VH, Hagedorn C et al (1984) Shade tolerance of grass and legume germplasm for use in the southern forest range. J Range Manage 37(3):229-232

Zanini GD, Santos GT, Sbrissia AF (2012) Frequencies and intensities of defoliation in Aruana Guinea grass swards: accumulation and morphological composition of forage. Rev Bras Zootech 41:905-913 